NBER WORKING PAPER SERIES

THE POLITICAL ECONOMY OF CONTROLS:

AMERICAN SUGAR

Anne 0. Krueger

Working Paper No. 2504

NATIONAL BUREAU OF ECONOMIC RESEARCH
1050 Massachusetts Avenue
Cambridge, MA 02138
February 1988

research reported here is part of the NBER's research program in International dies. Any opinions expressed are those of the author and not those of the National eau of Economic Research. 
NBER Working Paper \#2504

February 1988

\title{
The Political Economy of Controls: \\ American Sugar
}

\begin{abstract}
This paper outhines the gabient crarateristies gi comptint nodeis of economit regulation and controls. It then euamines the evolution gf the American sugar progran fron 1954 to 1987 in light of thesa models. While iobbying and other features of traditional nocis were clearly important, cther elements aiso pleyed a bay rela. in farticuiar, a technecracy devaloped, and complexity ơ reguigior sarved ae an important fector perpetuztirg the sugar program. Einilarby, loboying and the role of vasted interests was eiearly inportant in the evolution

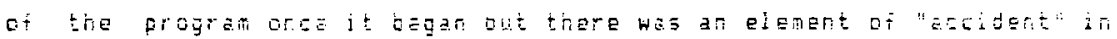
traprograns initiatian. once it enjotgd, it begane an inatrungt to ba captured and used by politicians, technocrats, and econonis antereats ล) $1 \mathrm{j}$.
\end{abstract}

nne 0 . Krueger

epartment of Economics uke University urham, N.C. 27706 
THE POLITICAL ECONOMY OF CONTROLS: AMERICAN SUGAR Anne D. Krueger

National Bureau of Economic Research, Inc. Working Paper Number 2504, February 1988

ERRATA, JUNE 1988

P. 1: In the acknowledgment footnote, please insert "Harvard University" in the last line after the University of North Carolina.

P. 5: Fourth line, strike "the" before "resources".

P. 10: Second from last line, insert "unless of course the price falls so low that harvesting proves unprofitable" after "output".

P. 16: Second line from bottom of text - 10 should be 30 .

P. 30: There's a typo in the first line of the first full paragraphi "enused" should be "ensued".

P. 32: Fourth line, first full paragraph: Please replace "The Canadians" with "Some Canadian firms".

P. 33: Three lines from bottom of text:

Please change 1986 to 1987. Also, please change the last two sentences in that paragraph to read: If sugar prices are to be maintained at their present levels, production controls will have to be instituted, stocks will have to mount, or subsidized exports will have to start. If the political process is unwilling to accept any of these three options, price supports will have to be lowered. 


\author{
Anne 0. Krueger*
}

In econonic theory, it is relatively straightforward to analyze the impact of politically-imposed controls over economic activity. Whether the control is over feedgrain prices in Egypt, the quantities of imports of individual itenms in India, price controls over "old" oil, or the "voluntary" reduction in the number of autonobiles exported from Japan to the United States, several conclusions follow straightforwardly. First and foremost, those controls (and most others) at best achieve their objectives in a a more costly manner than would alternative mechanisms. Second, the presumed beneficiaries of controls are of ten quite different from those (if any) actually benefitting. Third, the costs of controls seem to be largely ignored or misunderstood in political decision-making, at least in the first instance.

Despite these well-established results, controls seem to persist. A major challenge confronting those concerned with these costs is therefore to attempt to understand the reasons why the politial process of ten generates and perpetuates high-cost solutions to stated objectives. To establish an understanding of the political economy of controls would therefore appear to be a formi* I an heavily indebted to Paul Pecorino for valuable research assistance in preparation of this paper. Al Reifman was extremely generous with assistance in providing material from the Congressional Research Service. Richard Snape was exceptionally helpful and generous in commenting on the entire manuscript and in sharing his extensive lenowledge of the international sugar econony. Helpful comments and suggestions were made by menbers of the Political Economy Workshop at Duke University, and the International Economics Workshops at Virginia Polytechnic and State University and the University of North Carolina. 
dable, but important, challenge, if means are to be sought to attain political objectives through least-cost means.

Ian Little has been in the forefront among professional economists using their analytical tool kit to demonstrate the costs of controls in a variety of settirgs. His work has been instrumertal in convincing the vast majority of the economics profession that the econonic costs of controls are far greater than was generally thought two or three decades ago. It is therefore appropriate that an essay in his horor attempt to further understanding of the political econony of economic policy. To that end, this paper sets forth the various hypotheses that are implicitly or explicitly made by economists about the determinants of controls and regulations. It then subjects those hypotheses to scrutiny by examining how well they perform in explaining the political economy of one particualar set of controls, those pertaining to American sugar.

To that end, Section 1 contains a brief survey of the literature pertaining to the political mechanisms generating controls. The next several sections cover the essentials governing the production and distribution of sugar (Sect. 2); the origins of the Americ:n sugar Program (Section 3), and its evolution over the period from 1948 to 1987 (Sections 4 through 6). Section 7 then provides a critical examination of the evolution of the program from the viewpoint of the various hypotheses laid out in section 1. A final section provides some tentative conclusions.

Sect. 1. Models of Econonic Policy Formulation

The absence among economists' of a widely-accepted model of economic

1. There is a large literature among political scientists focussing on the 
policy formulation is readily illustrated by the divergent implicit and explicit assumptions about the rature of intervention underlying policy anaysis in the various subfields in economics. In international trade, the tradition was for long to assume that policy makers were uninformed and that failure to adopt Pareto-optinal policies reflected ignorance on their part. International economists assumed that a benevolent government would, once informed of the benefits of free trade, innediately undertake policy reform. Considerable bewilderment then resulted from the many departures from Pareto-optimal policies in circumstances where infant-industry and monopoly power in trade did not apply.

Several models of political-economic interaction in policy formulation have been set forth in an effort to understand the persistence of some policies. Notable anong them were Brock and Magee (1978), who modelled politicians as needing money to win elections but simultaneously losing votes if they support lobbyists' causes too ardently: an equilibrium occurs when the revenue from lobbying at the margin increases votes by the same amount as that lobbying activity loses votes. Corden (1974), by contrast, attempted to explain international economic policy as a consequence of a "conservative social welfare function": politicians attempt to protect peoples' income streans, and

determinants of policy formulation. I am heavily indebted to Robert Bates for long and useful discussions about this literature. In this section, I focus only on the economics literature on the subject, in part because of my own comparative advantage, but in part because the intent of the paper is to focus on political-economic interactions, and the role of market forces in affecting the outcomes of policies adopted by politicians, topics largely neglected in both the economics and the political soience literature. 
thus provide assistance to those who are adversely affected by shifts in prices and competitive positions. Finally, Bhagwati and Srinivasan (1980) modelled "directly unproductive activity", in which lobbyists spend resources in seeking legislation equal in value to the value of the protection to them.

In public economics, there has been a similar tradition: a presentation of economic efficiency conditions for optimality, with the accompanying assertion that nonfulfillment of these conditions - such as the presence of externalities - represented a case of market failure and therefore justified market intervention. Underlying these sets of policy prescriptions is the notion once again of government as a benevolent guardian, hampered only by ignorance of proper economic policy as it seeks disinterestedly in maximizing Benthanite social welfare.

In the field of industrial organization, by contrast, the tradition until the 1960s was to assume that government bureaucrats were in fact pursuing the public interest in regulating whatever was regulated - transport, communications, public utilities, and the like. This view was challenged, and largely overthrown in the 1970s by Stigler, Peltzman, and others, who instead posited full rationality of all actors. In this view, all political agents are rational and use the political process to effect wealth transfers. Thus, the view of the regulatory process changed fundamentally, as it was seen as a rational outcome to private maximization through the political process. All participants were seen to be fully rational and acting in their own self interest. In this model, policy analysis by economists would serve no useful purpose, as additional information would not change the behavior of any participant in the regulatory process.

An interesting variant on the Stigler-Peltzman approach has been set forth by Becker, who assumes that political interest groups form in their own self interest, and that politicians rationally choose policies in response to the 
competing pressures these groups can exert. With competition among groups, and the assumption that anything which benefits one group must either be financed directly by a tax or indirectly by costing another group (including deadweight losses), Becker concludes that the resources are allocated to the political process to maximize the benefits (which are for some groups negative) each group expects to receive.

Yet another approach is that of Mancur Olson. Starting with the "logic of collective action", in which the "free rider" problem prevents the effective collusion of large groups of small losers, Olson formulated hypotheses as to which groups would emerge and the characteristics of industries and of other economic interest groups that would be likely to be effective. Carrying his analysis further, olson attempted to explain differentials in growth rates among nations after the Second World War. In Olson's world, interest grups organize to protect their interests as growth progresses. Over time, more and more groups and institutions are in place, and in the process economic efficiency diminishes and growth decelerates. War destroys these groups and interests, at least to some extent, so that war-devastated countries, such as Germany and Japan are enabled to grow rapidly, freed of many of the resistances to growth that arise over time in a war-free environment. 2

Olson's model essentially posits that economically-inefficient outcomes arise because of free rider problems: it is rational for individuals not to join groups interested in consumer welfare, etc., because the benefits to them are independent of their own activites. This contrasts significantly with the Stigler-Becker view in two ways: institutional means are not available for

2. See Mueller for a series of papers examining the empirical validity of the Olson hypotheses regarding growth rates. 
large groups of small pootential gainers or losers to represent their interests, and interest groups form gradually over time as they learn about their interests (and possibly respond to the gains of other groups).

The final view of the political process is that of Buchanan and the public choice group. Here, the underlying assumption is that individuals behave in their interest in the political, as well as the economic, arena, but that the "rules of the game" in the political arena may permit choices that, while individually rational, could clearly be improved upon by a different decision rule. As Buchanan has put it:

"Economists should cease proferring policy advice as if they were employed by a benevolent despot, and they should look to the structure within which political decisions are made...." (Buchanan, P. 223).

Each of these models has testable hypotheses underlying them. Do politicians anticipate the outcome of their controls? Are they acting in their own self-interest, or the self-interest of the voters whom they represent in any sense? Do lobbyists and other pressure groups always know and act in their self-interest?

However, an important difficulty is that it is not obvious how one could systematically collect data that would provide for statistical estimates of, e.g., the fraction of time that politicians were influenced by lobbyists and the fraction they represented their constituents or how one could measure the pressures confronting politicians.

Thus, to date the variety of models of political-economic interaction have not been subject to empirical testing. Yet empirical evidence with regard to behavior is essential if progress is to be made in better understanding of the political economy of controls. 
In an effort to start providing empirical evidence, this paper is devoted to trading the evolution of controls in one particular market - American sugar - over time. The essay covers controls over prices, production, and imports of American sugar from 1934 to the present are analyzed herein, in the hope that an empirical understanding of one set of interactions between markets and politicans, and of the evolution of one set of controls over time, may be suggestive of some of the missing links in a fuller paradigm of the political economy of controls, and possibly of a methodology for empirically assessing a number of controls to such scrutiny. In Sect.8, the competing.assumptions about behavior underlying the models set forth above are scrutinized with respect to the experience with American sugar.

\section{The Sugar Market}

The eonomic effects of the American sugar program have been extensively analyzed, and are reasonably well known. In this section, the essential characteristics of the sugar industry, and the relation of the American market to the international sugar market are described. Emphasis is on those aspects relevant for analyzing the political economy of controls, at least as exemplified in the case of sugar.

\subsection{The Production Function ${ }^{3}$}

Sugar is an unusual commodity. It can be made from either raw cane or sugarbeets, and yet the end products of the two are perfect substitutes. Cane can grow only in tropical or semi-tropical climates while sugarbeets are grown in temperate climates. Both cane and beets require processing to make sugar.

3. This section draws heavily on Landell Mills (1985). The interested reader can consult that source for considerably greater detail. The facts, however, are in virtually all hearings pertaining to the sugar program. 
In both cases, initial processing must be undertaken within a very short time after harvest; it must therefore be done close to where the cane or beet is grown.

For beet sugar, a single stage refining process has produced refined sugar since the late 1800s. In the case of carle, however, second stage refining is nececssary to make refined sugar; raw sugar (i.e., that processed from cane near the site) can be refined anywhere." While there are a few byproducts of cane and of beet, they are not sufficiently valuable to warrant growing the crops in the absence of a demand for their sugar; at any event, the byproducts made from cane and beet are similar.

Cane and beet mills, and cane refineries are capital intensive, and apparently have little or no alternative use. No farmer would consider growing cane or sugarbeet without a processing plant nearby, and no processor lof raw cane and of sugarbeet - cane refining is different) would consider establishing a plant unless there were a proximate source of supply. For this reason, there is a considerable degree of vertical integration in the industry; in Hawaii, for example, most cane is grown in fields owned by the same parties who own the local sugar mill for first-stage refining.

Mills need a fairly steady flow of cane/beet in order to utilize their capacity reasonably steadily over a major part of the year. Arrangements for harvesting sugarbeet and cane therefore include fairly detailed provisions as to the date of delivery of the product to the mill.

4. The United States had a tariff on raw sugar imports, and a higher tariff on refined sugar imports throughout most of the 19 th century. At that time, beet sugar required second-stage refining.The differential in tariffs between raw and refined sugar was high enough to make the effective rate of protection to refining greater than 100 percent. The best means of determining whether sugar had been refined was the "Dutch color test" which graded imports by the extent of brown coloration of the sugar being imported. Among the 19th century problems with tariff administration was the importation of brown refined sugar. See Taussig 1924, Pp. $101 \mathrm{ff}$. for a full description. 


\subsection{The Demand for Sugar and Sweeteners.}

More than 70 percent of U.S. sugar consumption is by industrial users bakeries, soft drinks, confectionary, cereals, etc.. The remaining 25-30 percent of consumption goes through distribution directly to consumers (defined as all sugar sold in bags of less than 50 pounds).

Consumption of refined sugar in the United States peaked at about 10.7 million pounds in 1972, equivalent to about 102 pounds per capita. At that time, per capita consunption of all caloric sweeteners (corn sweeteners, honey, etc.) was 13.3 million tons, or 25.1 pounds per capita.5 By 1986 , American consumption of sugar had fallen to $7.44 \mathrm{million}$ tons, or 61.1 pounds per capita, while total caloric sweetener consumption had risen to 15.898 million tons or 130.4 pounds per capita. ${ }^{6}$

\subsection{The International Sugar Economy}

5. This contrasts with an estimated consumption per capita of 9 pounds in the United States in 1822 (see Johnson, P.5). Here and throughout, the reader should be alert to units: production is often measured in terms of tons of cane or beet; these units (contrast Tables 2 and 3 below) are obviously different from those that measure the weight of refined sugar produced or consumed. Since the yield of cane and beet varies from year to year and place to place, conversion ratios are not a constant. However, the conversion factor is close to 10:1 - for example in 1986, 28.743 tons of cane were produced, which was 3.4 million tons of sugar, raw value. For beet, 25.229 tons were produced, with 2.989 million tons of sugar, raw value produced. See USDA, Sugar and Sweetener Situation and outlook Yearbook, June 1981. For an amusing discussion of the problems of administering an import quota set in terms of raw value, see House Hearings $1974, \mathrm{Pp} .95-101$.

6. Consumption of non-caloric sweeteners has also risen; in 1970 it is estimated that they accounted for 5.8 pounds per capita consumption, while by 1987 they were 18.5 pounds per capita. There are many grounds for believing that much of the increase in consumption of noncaloric sweeteners may have represented a shift in tastes, rather than a consequence of relative price changes. For that reason, the evolution of noncaloric sweetener production and consumption will not be further considered in this paper. Taking it into account would not significantly alter the argument at any stage, as total consumption of noncaloric sweeteners still occupies less than 15 percent of the combined narket. 
There are few countries in the world that do not intervene in their domestic sugar markets. Perhaps this is because both temperate and tropical countries can grow sugar. Regardless of the motives for intervention, the result is that about three quarters of sugar grown in the world is consumed in the country of production.

For this reason, the international market is somewhat thin, with about 27 million tors out of an estimated total world production of about 100 million tons (sugar equivalent, both cane and beet) entering into international trade (Sugar and Sweeteners Situation, June 1987, P. 35) in the $1985 \backslash 86$ crop year. Even out of that total, the existence of a number of preferential arrangements (including the American quota and Cubun-USSR trade) has meant that the "free market" price has governed only a small fraction of transactions. American preferences are diminishing in importance, however, as American imports have fallen, for reasons that will become evident below, from 6.2 million tons in 1977 to an estimated 1.5 million tons in 1987.7

The price of sugar has always displayed volatility on international markets. Two factors contributed to this. First, there is an eighteen month lag between planting of cane and first harvesting. Thereafter, cane is usually cut two more times at approximately six month intervals before the field is cleared and a new crop planted. Thus, when sugar prices rise, there is a longer time-lag than for annual crops (although not as long as for some tree crops) before additional production reaches the market. When the sugar price falls, it is an even longer time before the planting response is reflected in reduced sugar output. Second, and at least as important, the fact that the international market is a residual has intensified these price shings.

7. In December 1987, the United States Department of Agriculture announced that the permitted level of impoits for 1988 would be 750 thousand tons. See New York Times, December 16 1987, P. 29. 
Thus, after Cuba lost her U.S. quota in 1960, world prices rose for several years. Thereafter, new plantings (which took place predominantly in countries which received higher sugar prices because of their increased quotas in the American market) matured, and world sugar supplies rose sharply; the world price fell from a high of 8.5 cents per pound in 1963 to 1.86 cents per pound in 1966. That, in turn, apparently discouraged plantings, because by 1969 the sugar price was rising again. However, because of the worldwide commodity boom, the production response was apparently more sluggish and delayed than in earlier periods of high prices. Hence, the price of sugar rose continuously until November 1974, reaching over 40 cents per pound in that month. There then followed another sharp decline in price as new supplies appeared by 1976 , and the price fell for the next two years. By 1980, however, production had once again responded to lower prices, and the price again rose sharply, reaching 29.02 cents per pound by the end of 1980 .

Thereafter, the world price fell and remained depressed for a long period as American imports declined sharply and the European Community increased exports as its production surpluses mounted. It was estimated in 1985 that, if all countries were to adopt free trade in sugar, the world price would be about 12 cents per pound.9 That contrasted with an actual price at the end of that year of about 4 cents per pound and a U.S. price of 20.3 cents per pound.

8. Cuba's exports and quota constituted the vast majority of sugar imports into the United States prior to 1960. In 1959, for example, Cuba exported $3,437,582$ million tons to the United States out of total imports of 4,273,000 tons. This contrasted with donestic production of $4,702,619$ million tons in that year. By 1961, Cuba's exports to the United States were zero. See Senate Finance Committee, Hearings on Extension of the Sugar Act of 1948,1965, P. 11.Cuba's estimated share of the world sugar trade was 28.6 percent in 1961, and 24.67 percent in 1984 . The Soviet Union replaced the United States as the major market for Cuban sugar in the 1960s. See Tan for particulars of the Soviet-Cuban sugar trade.

9. See Leu and Knutson for one attempt to estimate what the world price would be in the absence of the current U.S. program. See also Landell Mills. 
By 1987, however, the world price was once again rising fairly sharply, reaching about 9.5 cents per pound by the end of the year despite the cutback in American imports and continued European exports.

\section{Origins of the Sugar Program ${ }^{\circ}$}

There have been few years in American history when sugar has not been the object of some degree of intervention. It has always been an importable. Starting in 1796, a tariff on imports was imposed, and until the late 1800s, revenue was the major motive for the tariff, as domestic production was less than ten percent of consumption, with inports supplying more than 90 percent of the U.S.market.11

Hawaii's relationship to the United States in the $1870 \mathrm{~s}$ and $1880 \mathrm{~s}$ was heavily centered around sugar: a free-trade agreement with the United States had permitted Hawaiian sugar to be imported without duty, and had encouraged the expansion of Hawailan cane growing land. The American Congress then proceeded to rescind the duty on sugar, but to pay a bounty of 2 cents per pound (about the sane as the specific tariff earlier collected and equivalent to 100 percent nominal protection) to American growers. The desire to have access to the American market at favorable prices seems to have been a major motive behind Hawaiian accession to U. S. jurisdiction, after which the U.S. reverted to tariff protection and Hawaii escaped the sugar tariff. From the

10. This section draws heavily on Terpstra. Only those aspects of the pre-1934 sugar tariff relevant for later development are discussed here. For a full account, see Taussig 1924, Part II.

11. House Agriculture Committee Hearings of 1951; Extension of the Sugar Act of 1948. HR 4521, Pp. 34-35. Taussig attributed the expansion of sugarcane production in Louisiana in the 19th century to the existence of the protective tariff, and documented U.S.D.A. efforts in the late 19th century that led to the development of sugarbeet production in the United States. Taussig, 1924, Chapters IV and VII. 
1890s until 1930, Anerican tariff protection continued. Because the Hahaiians were exempt from the tariff (and Cuba also received a twenty-five percent reduction in duty/12, they benefitted from protection in the sheltered American market. The Philippine sugar industry also started under the umbrella of American protection.13

The Smoot-Hawley tariff, however, raised the rate of duty faced by Cuba to 2 cents per pound (compared with a world sugar price of .73 cents a pound in 1932), and the duty on imports from other countries to 2.5 cents per pound for other exporting countries. In fact, however, imports from Cuba and the Philippines met U.S. demands, and little sugar was imported from other countries. Indeed, during some periods of the year, the sugar price fell below the world-price-cum duty as Cuban sugar was more than sufficient to meet demand at that price.

During the Great Depression, sugar prices fell drastically. Among other consequences, the Cuban economy was extremely adversely affected, and with it, the fortunes of American investors who owned sugar plantations there. As part of New Deal legislation attempting to cope with the crisis, the Jones Costigan Act of 1934 was passed. It provided for a system of production and marketing quotas for domestic producers and import quotas for foreigners (almost exclusively Cuba). The intent of the Jones-Costigan Act seems to have been primarily to shore up the Cuban economy and to increase American producers' incomes. There was, in addition to production and import restric-

12. Cuban sugar production rose rapidly in the first three decades of the century in response to this partial exemption. Much of the cane was planted, harvested, and processed (first-stage) on American-owned land and sugar mills. By 1934, it was estimated that Americans owned 70 percent of Cuban sugar producing capacity. (1934 Hearings, P. 106). See also House Hearings, 1952, P. 35.

13. Again, see Taussig, Ch. 6 . 
tions, provision for direct payment to American producers. However, there was also a clear intention to contain the size of the industry. In his message to Congress, President Roosevelt's statement was that:

"Steadily increasing sugar production...has created a price and marketing situation prejudicial to virtually everyone interested. Farmers in many areas are threatened with low prices for their beets and cane, and Cuban purchases of our goods have dwindled steadily as her shipnents of sugar to this country have declined.

" There is a school of thought which believes that sugar ought to be on the free list....

"I do not at this time recommend placing sugar on the free list. I feel that we ought first to try out a system of quotas with the three-fold object of keeping down the price of sugar to consumers, of providing for the retention of beet and cane farming within our continental limits, and also to provide against further expansion of this necessarily expensive industry..."14 Like much of the New Deal legislation, the Jones-Costigan Act was passed quickly within several days of its introduction and after hearings lasting only a few hours.15For later reference, it is interesting to note that sugar producers opposed the initial act. Beet growers were particularly adamant in their opposition as the act called for a 17 percent reduction in sugarbeet production from 1933 (See 1934 hearings, Pp. 84,118,

$121,132,145,148,152,167.16$

14. Sugar Beets and Sugarcane as Basic Agricultural Commodities Under the Agricultural Adjustment Act, H.R.7907. February 19, 1934, House Hearings, P. 1. The Chief, Section of Sugar and Rice, Agricultural Adjustment Administration, testified that the domestic sugar industry was "an expensive one from the point of view of

the consumer and that lies behind the freezing of sugar beet acreage." P. 13.

15. See Ibid.

16. Because sugar was an import, its regulation should have come under the jurisdiction of the House Ways and Means Committee and the Senate Finance Com- 
Even in the 1934 legislation, sugar refiners sought quotas to restrict imports of refined sugar. They claimed that the 1930 legislation (Smoot Hawley) left them with a cost disadvantage vis-a-vis foreign producers (because the Congress had assumed that it took one ton of raw sugar to make a ton of refined, whereas the actual conversion ratio was more like 1.07 to one.17 So, quotas on imports of refined sugar were imposed to satisfy domestic (second-stage) refining interests; the quota was later replaced with a prohibition - a necessary condition for preserving the support of the sugar refiners who imported the raw (cane) sugar and refined it in their plants.

The initially recommended quotas were set with a base equal to the preceeding three years marketings. The average marketings over that period had been (in millions of tons of sugar, raw value):

Continental beets $1,450,000$
Continental cane (from Louisiana and Florida) $1,260,000$
Hawailian cane $\quad 935,000$
Puerto Rican cane $\quad 821,000$

mittee. It did come under the latter. But one of the interesting "accidents" with important consequences was that when the Jones-Costigan Act was first up for renewal in 1937, the Chairman of the House Agriculture Committee requested, as a favor from his colleague and friend, the Chairman of the Ways and Means Committee, that the House Agriculture Comnittee handle sugar matters. The Chairman of the House Ways and Means Committeeacceeded to the request, and the House Agriculture Committee has handled sugar matters ever since.See Price for an account. Because there is a tax on sugar imports, only the House may initiate legislation. This right of initiation, combined with the fact that sugar is the only agricultural commodity considered by the Senate Finance Comittee has resulted in unusually great power concentrated in the hands of the House Agriculture Committee for dealing with sugar. See the discussion of the 1962 bill below for one instance where the senate opposed the House decisions but in the end was unable to prevail.

17. Johnson (P. 30) believes that American refineries had lost their comparative advantage in the 1920 s and used the 1.07 to one conversion ratio as an argunent for protection which they needed on other grounds. Taussig's documentation, however, suggests that the protection accorded to American sugar refineries as early as the 1870 s was more than sufficient to provide needed protection and moropoly profit. See his interesting discussion of the "Sugar Trust"(Taussig, 1924, Ch. VIII). Taussig cites testimony before Congress in 1888 by the head of the American Sugar Refining Company (the Trust) to the effect that "the mother of all trusts is the customs tariff bill". Taussig 1924, P. 104 . 


$$
\begin{array}{lr}
\text { Philippine cane } & 1,037,000 \\
\text { Cuban cane } & 1,944,000 \\
\text { Virgin Islands cane } & 5,000 \\
\text { Total } & 6,452,000 \text { tons }^{18}
\end{array}
$$

As already indicated, the sugar growers opposed the introduction of these quotas in 1934, feeling it was against their interests. Whien the bill came up for renewal in 1937, however, they had switched sides, and actively supported the sugar program and production and import quotas. (See pp. 16-45 of the 1937 House Hearings). Interestingly, a representative of the United States Sugar Corporation (based in Florida) opposed the 1937 bill on the grounds that Florida could expand production and indicated a preference for unrestricted sugar imports unless Florida's quota was increased substantially (P. 168 of House Hearings, 1937). Louisiana growers also asked for larger quotas, while beet producers had not even filled their quotas under the original 1934 Act. (P. 145 of 1937 Hearings). Representatives of both Puerto Rico and Hawaii both advocated the removal of restrictions on their exportation of refined sugar to the mainland (P. 55, 106).

The sugar program was again renewed in 1940. With the advent of the Second World War, however, it was naturally suspended as the problem became one of increasing output, rather than controlling supply. During the war, Cuban sugar was exported to the United States, even when American prices were below those that could have been realized in other markets.19.

\section{The "Support Cuba" Period: $1948=1960$.}

After the War, the Sugar Act was reconsidered in 1948. At that time, of course, the world price was high (although the U.S. price was about 10 percent above it) and the real issue was the percentaged of sugar that should be sup-

18. Data from P. 2 of House Hearings 1934.

19. Sugar Act of 1948, House Agriculture Committee Hearings of 1947. Pp. 4244. See also Gerber for a discussion. 
plied from domestic and foreign sources. A major consideration in devising the legislation was the moral debt owed to Cuba, because of Cuban steadfastness in providing sugar to a wartime ally. As passed, the intent of the legislation was to "protect foreigners' interests in the U.S. market". This was to be accomplished by continuing to restrict U. S. production to 55 percent of consumption and allocating the remaining rights to supply the high-price U.S. market to foreign countries, which in practice meant primarily cuba.20

By virtue of the production controls, the U.S. price would be higher than the foreign price by more than the tariff; rights to sell in the $U$. $S$. market would therefore be valuable. It was clearly the intent of the administration that these rights be directed largely toward Cuba. Te Cuban share was 98.64 percent of the total import rights and Cuba also received rights to unfilled quotas of other countries. In 1949, for example, the United States imported 3.103 million tons of sugar from Cuba, 525 thousand tons from the Philippines, and 56 thousand tons from all other foreign countries (Senate Finance Committee Hearings, 1965, P. 19).21

20. House Agriculture Cormittee Hearings of 1951, HR 4521, Extension of the Sugar Act of 1948, pp. 34-35. The 55-45 formula had been set in the $1937 \mathrm{Ex}-$ tension of the Jones Costigan Bill.

21. The Philippine sugar industry was initially bolstered by the Payne Aldrich Tariff Act of 1909 which gave the Philippines the right to export 300,000 tons duty-free to the United States. The duty-free allotment had then been expanded during the First World War. The Philippine production of sugar had expanded greatly in the $1930 \mathrm{~s}$. According to the U. S. Tariff Commission, "the most rapid expansion in both acreage and production occurred in the years 1932-34, when the question of Philippine independence was being debated by Congress. Inasmuch as the several independence bills then under consideration provided for quotas on sugar to be allocated to individual mills and to planters on a production basis, there was an incentive to increase output and hence quota allotments. As a result, Philippine sugar production reached a peak of $1,509,000$ short tons in 1934. Since that year it has declined because of the quota provisions of the Jones-Costigan Act and the Independence act." U.S. Tariff Commission, P. 45. After the Second World War, the Philippines were again to be favored with quotas; initially, however, it was recognized that war damages would prevent their filling their quotas and the unfilled portion was allocated to Cuba. 
It is perhaps significant that only one sugar consuner testified in 1948: the American Bakers Association submitted a short letter indicating its support of a one-year extension of the Sugar Act, and urging a study of the effects of the sugar program (P. 54 of House Hearings).

The sugar program was changed very little throughout the 1950s. Cuba's share of imports fell somewhat as other countries' production increased, but remained at 3.4 million tons in 1958, contrasted with 980 thousand tons from the Philippines and 291 thousand tons from all other foreign sources. The Sugar Act was renewed in 1951 to continue through 1956, and it was again extended in 1956 to last through 1960. The 1956 extension differed from the earlier ones in that production quotas for U.S. producers were increased along with foreign quotas, so that Americar producers would maintain their share in the American market. Thereafter, market growth in excess of 8,350,000 tons was to be shared $55-45$ between domestic and foreign producers. ${ }^{22}$

As an indication of how complex formulae can become, the 55 percent additional domestic production quotas were to be distributed as follows: of the first 165,000 tons of increased quota, 51.5 percent was to go to sugarbeet and 48.5 percent to mainland cane; the next 20,000 and 2,000 tons were to go to Puerto Rico and the Virgin Islands respectively, and increases in excess of 188,000 tons were to be allocated in proportion to the initial quota allotments. (Ibid., P. 37).For foreign countries' 45 percent additional allocations, 43.2 percent was to go to Cuba, and 1.8 percent to other foreign countries in 1956, while in subsequent years Cuba was to receive 29.59 percent and 15.41 percent was to go to other foreign countries: the Philippines,

22. Data are from U.S. House of Representatives, Commitee on Agriculture, The United States Sugar Progran, 1971, P. 37. 
however, was not to receive any change in quota. Meanwhile, if any domestic areas failed to fill their quotas, these should be reallocated to other domestic areas and Cuba only.

During the 1950s, acreages allocated to cane and sugarbeet in the United States remained relatively constant, but production increased somewhat due to rising yields. In 1950, 406,000 acres of cane and 924,000 acres of sugarbeet had been harvested with yields of 34.9 tons and 14.7 tons per acre respectively. By $1960,406,600$ acres of land were devoted to sugarcane and 897,000 acres were devoted to sugarbeet. Yields had risen respectively to 40.0 and 18.7 tons per acre. ${ }^{23}$

\section{Expanding Domestic Production and Acreage, 1962 to 1974}

\subsection{The Battle over the Cuban Quota}

A major shift occurred after 1959, however, as American relations with Cuba soured. A first step was to amend the earlier legislation to permit the President of the United States to determine the Cuban quota for the period June 1960 to June 30, 1962, and to permit imports from alternative sources not to exceed the amount by which the Cuban quota was reduced. Cuba's quota was thereupon reduced to zero from July 1960.

A political battle over the future of government policy toward sugar then ensued. The original motives for the 1948 Act were no longer valid. One solution, advocated by economists in the Administration and outside the government, would have been to abandon quotas both on domestic production and on imports, and to permit a return to free markets; if not that, at least a global quota (rather than country-specific allocations) would have made sense and were in fact finally supported by the Kennedy Administration. The domestic

23. Data are from USDA ERS 1985. 
growers, and especially beet growers, however, seized the opportunity to urge that their production quotas be increased to make up part of the Cuban shortfall, and advocated a continuation of the program.24 It should be noted, however, that from an econonic self-interest standpoint, domestic producers and processors had an interest in restricting imports, but it is not evident that country-specific quotas were in any regard more favorable than a global quota.

However, interests of the refiners of raw (i.e. cane) sugar did diverge from those of growers of cane and sugarbeet, and from those of beet and cane millers: reducing the quantity of raw sugar imported and increasing domestic production would necessarily reduce economic activity for raw sugar (cane) refiners. For mostof the (second-stage) refiners of cane were lacated primarily in coastal areas, where imports of raw Cuban sugar (once-processed cane) had once been refined. Insofar as domestic beet would substitute for imported cane, new sugarbeet processing capacity would be built near beet growing areas, and second-stage cane refiners would not receive raw cane sugar in quantities commensurate with their capacity.

After Cuba lost her quotas, the Chairman of the House Agriculture Committee apparently wanted to reassign a large share of the Cuban quota to the Dominican Republic, at the same time as the State Department was preparing sanctions against the Dominican Republic (under Trijillo). As described by Cater,

24. It should be recalled that the early 1960s were a time of "surplus production" of agricultural commodities under agricultural price support programs. This enabled advocates of expanded sugar growing areas to argue that enactment would reduce the extent of surpluses of other commodities. For an account of the political forces that determined the outcome in 1962, see Berman and Heineman. 
"Quite a struggle ensued. For a period, it remained doubtful whose foreign policy would prevail - the U.S. government's or the sugar subgovernment's. Chairman Cooley forced a temporary increase of the Dominican quota, but the U.S. Treasury slapped a special tax on it. With the change of Administrations in 1960, Executive resources were wheeled into the battle, Attorney General Robert Kennedy nade it known that he was examining the spending habits of the affluent Dominican lobbyists for evidence of "improper" efforts at persuasion...At long last, Mr. Cooley retreated, and soon afterward General Trujillo fell....Despite President hennedy's desire to move toward a "global quota" purchased at nonpremium pricess, the old arrangement...has been preserved largely intact." (Cater, F. 19-20).25

Although opposition to the bill arose both from those opposing giving something of value to foreigners and from those who wanted to protect domestic growers, the Sugar Act of 1962 nonetheless passed in a form which enlarged and/or extended quotas to other foreign producers but simultaneously allowed for increases in domestic production. ${ }^{26}$ Thus, total acres of cane and beet harvested rose from $1,370,000$ in 1960 to $2,065,000$ in 1970.27

25. The 1962 Congressional Almanac commented that "Although sugar legislation is not a partisan issue, it has touched off some major Congressional battles in recent years. In general, the Senate has supported the Administration, while the House has followed the lead of its Agriculture Committee, where sugar legislation originates.

... In 1962, the Administration and the House were in accord on increasing domestic quotas, but differed sharply over the foreign quota provisions, with te Administration resisting reassignment of a portion of the reserved Cuban quota to other countries on a permanent basis, and the House supporting such reassignment...A controversy arose over the role of lobbyists representing foreign interests, who stood to gain large fees if their clients' countries received quotas..."1962 Congressional Quarterly Almanac, P. 128. I am indebted to Rick Harper for calling this article to my attention.

26. The version passed in the Senate was considerably more liberal than that passed in the House, but it was the House's version that survived the conference committee. See Berman and Heineman for an account.

27. Almost all of this increase took place on the U. S. mainland. Acreage planted in Hawaii rose about 200,000 acres between 1960 and 1970. However, acreage and production in Puerto Rico declined over this period, apparently 
The 1962 Amendments to the Sugar Act of 1948 included a provision under which there would be acreage allotments granted to yield 65,000 short tons, raw value of beet sugar. Localities were to be selected without regard to earlier producing history, in accordance with the following criteria:

"fimuess of capital comnitment for construction of factory facilities, need for a cash crop, distance from other producing localities, suitability for sugarbeet production and accessibility to sugar markets..."

157,000 acres were committed to localities in which six new beet mills would be constructed, and another 15,000 acres were allotted in areas where existing mills were thought to have additional capacity.28 Over $\$ 20$ million was invested in additional beet refining capacity. The designated localities were Mendota, California (1963), Herefore, Texas (1964), Drayton, North Dakota (1965), Montezuma, New York (1965), Easton, Maine (1966) and Chandler, Arizona (1966).29

Cane production and milling capacity were also expanded: during the 1960s, eight new raw sugar mills were constructed in Florida, so that there were nine large mills in 1970 compared to three in 1960.

due to the high costs of production relative to other $U$. $S$. sources. It is difficult to determine the reason for Puerto Rico's apparent cost disadvantage. Sugar was grown on small farms in Puerto Rico, and it is probable that scale economies, combined with rising real wages in Puerto Rico resulted in unprofitability of the crop. There is some discussion of Puerto Rico in the House Agriculture Hearings of 1974 on the Sugar Act Extension of 1974, P. 293.

28. U.S.H.R. "The United States Sugar Program", 1971. P. 39.

29. Thirty six Congressmen were on the House Agriculture Committee for the 87 th Congress The Chairman was from North Carolina and the Vice Chairman from Texas. There was no Congressman from Arizona on the Committee and there were Congressmen from states with more apparent suitability for sugarbeet production than some of those mentioned above. (Comnittee membership included a representative from Idaho, two from Kansas, two from Iowa, and two from Oklahoma.) There were three Congressmen on the committee from cane-growing states (Hawaii, Louisiana, and Florida). See 1961 Congressional Quarterly Almanac, P. 48 . 


\subsection{Administration of the Program}

The Sugar Act was renewed, with amendments, until 1974. There were difriculties in both administration and enforcement during these years. For example, sugar tended to be shipped to the United states early in the quota period, leaving U.S. refiners with storage problems. The U.S. Department of Asriculture therefore began restricting the amount of sugar that could be imported under quota in the first part of the year.3n

There was also a problem of how to keep domestic acreage within the desired limits. For some regions, including Hawaii for the entire post-rar period and Puerto Rico after 1956, this was not an issue as prices were not sufficiently high to induce increased plantings. For other areas, however, the Secretary of Agriculture was to determine "proportionate shares" to be allocated to individual farms. These shares were the fraction of a region's allotment that could be produced by the individual farm. These proportionate shares were enrorced by a "conditional payment" granted to farmers staying within their allotments, which constituted an important part of their income. Farmers could feed excess cane or beet to livestock without penalty but could not sell it to the mill; the mill, in turn, could buy it legally but would not have been able to market it and therefore had no incentive to do so.

This, in turn, caused difficulties in areas where it appeared there would be excess production, because each producer wanted to sell to the mill before the mill's allotment was exhausted. When this happened, "panic selling" started. To stop this, the Secretary of Agriculture was entitled to impose Marketing Allotments for individual farms, indicating the proportion of each farmer's crop that could be sold to the mill.

\footnotetext{
30. House Agriculture Conmittee, The United States Sugar Program, op. cit.,
} 
Then, too, criteria had to be established for the allocation of foreign quotas. ${ }^{31}$ These included:

1. There must be friendly governments with which the linited States had diplomatic relations, which did not discriminate against American citizens and which indemnified for any property expropriated.

2. "Dependability as a source of sugar supply as reflected in the country's history in supplying the U.S. market, its maintenance of sugar inventories ard its potential for supplying additional sugar upon call during critical periods of short supply." (U.S. Sugar Program, P. 49)

3. The country's imports from the United States, with particular attention to its imports of agricultural commodities.

4. "Need of the country for a premium priced market ...including (a) reference to the extent it shares in other premium priced markets, ${ }^{32}$ (b) its relative dependence on sugar as a source of foreign exchange, and (c)present stage of and need for economic development). (Ibid, , p. 49).

5. "Extent to wich benefits of participation of this market are shared by factories and larger land owners with farmers and workers together with other socio-economic policies in the quota countries." (p. 49 again)

6. Location of country, including considerations of how supplies might be affected in case of emergencies.

31. There were also criteria for the allocation of quota deficits, but these were even specific with respect to the country in deficit, and are not covered here.

32. This was primarily a reference to sugar exports tothe United Kingdom under the Commonwealth Sugar Agreement. 
There were also provisions for the imposition of quotas upon the importation of sugar-containing products in the event it was determined that these would affect the U.S. sugar market and the implementation of the program. Finally, there was even quota-exempt sugar importation, for the following situations:

"1. The first ten short tons, raw value, of sugar or liquid sugar imported from any foreign country, other than Cuba and the Republic of the Philippines";

2. The first ten short tors, raw value, of sugar or liquid sugar imported from any foreign country, other than Cuba and the Republic of the Philippines, for religious, sacramental, educational, or experinental purposes;

3) Liquid sugar, inported from any foreign country, other than Cuba and the Republic of the Philippines, in individual sealed containers of such capacity as determined not in excess of one and one-tenth gallons each; and

4) any sugar or liquid sugar imported, brought in, or produced or manufactured in the United States (a) for livestock feed or for the production of livestock feed, or (b) for the distillation of alcohol (including all polyhydric alcohols), or (c) for the production (other than by distillation) of alcohol, including all polyhydric alcohols, but not including any alcohol or resulting by-products for human food consumption or (d) for export as sugar or in sugar-containing products." (U.S. Sugar Program., p. 64).

\subsection{Interest Groups}

These adninistrative complications notwithstanding, the Sugar Act continued to be approved, with amendments until $1974 . .^{3}$ Long before that, various groups interested in the sugar program had organized themselves. There was a

33. The Chairman of the House Agriculture Bill introduced one set of amendments to the bill to the House with the introductory statement that the bill was so complex that no one could understand it, and it would be necessary for Congressmen to take his word for it! 
Sugar Users Group (consisting of bakers, soft drink bottlers, candy and confectionary manufacturers, etc.) and a Sugar Producers (the growers, millers, and refiners) Group, growers associations in all the main regions, associations of refiners (of imported raw sugar) and of beet mill operators, and so on.

Foreign lobbyists were also important. Cater, in his Washington expose of 1964, focussed inter alia on the "sugar subgovernment". As he described it,

"since the early 1930s, this agricultural commodity has been subject to a cartel arrangement sponsored by the government. By specific prescription, the sugar market is divided to the last spoonful among domestic cane and beet grovers, and foreign suppliers. Ostensibly to insure "stability" of supply, the U.S. price is pegged at a level considerably above the competitive price in the world mirlket...

Political power within the sugar subgovernment is largely vested in the Chairman of the House Agricultural Comnittee who works out the schedule of quotas. It is shared by a veteran civil servant... who provides the necessary "expert" advice for such a complex marketing arrangement. Further advice is provided by Washington representatives of the domestic beet and cane sugar growers, the sugar refineries, and the foreign producers."(Cater, P. 18)

\section{Cessation of the Sugar Act, 1974 and the Era of No Program, 1974-1981}

During 1973-74, the price of sugar skyrocketed, rising from 9.61 cents per pound on the world market in 1973 to 44.97 cents per pound at the end of 1974 , having reached a high of 57.17 cents in November of that year. The Sugar Act was up for renewal and came to a vote during the period of high prices. At that time, the U.S. price was a little below the world price, so that the quotas to recipient countries were valueless and there was no protection to American producers. Indeed, there was discussion in the hearings as to whether 
it was "reasonable" to expect Hawaiians to ship raw sugar to the mainland when they would receive a higher price in Japan. Sinultaneously, consumer groups were protesting high retail sugar prices, which reached a dollar a pound at the retail level at about the time the hearings were held.14

The National Consuner Congress testified in favor of failing to renew the Sugar Act, elininating all quotas, and going instead to an income-support basis for sugar growers. The consuner group also advocated efforts to reach an international agreement to stabilize sugar prices.35

The Department of Agriculture supported extension of the Sugar Act, but wanted to end donestic quotas and direct payments. It also requested a 3-year extension (only) of the program, with the stated intent of considering ways of bringing the sugar program under general agricultural legislation. The Sugar Users Group reconmended a two-year extension of the program, and advocated a wide corridor for the price targets of the Secretary of Agriculture. Simultaneously, it opposed bringing other sweeteners under the program or controlling them in ary way. The National Confectioners Association also supported extension of the bill, but advocated quotas on inports of conectionary imports as an essential part of the legislation.

Thus, support still appeared strong for a sugar program, but it was less cohesive than had earlier been the case and the various producer and user groups could not agree on what they wanted. The House Agricultural Committee passed a bill, but it was defeated on the House Floor, and the Sugar Act was not renewed. As a consequence, sugar was hithout a special program. It still

34. See Council on Wage and Price Stability, 1975.

35. House Hearings 1974, P. 164. 
fell under the general provisions applicable to agricultural commodities, however and thus renained subject to agricultural prpice supports. In addition there remained a duty on imported sugar.

During the early 1970s, a technology for producing a virtually-perfect substitute for sugar in liquid uses fron corn (high rructose corn syrup HFCS) was developed. Until the high sugar prices of 1973-74, however, it was uneconomic relative to sugar. With those prices, however, HFCS came to be produced in increasing quantities and to be used instead of sugar in some commercial uses.

In 1978 , a new sugar act was proposed. For the first time, the sugar refiners testified against it. The representatiave of the U.S. Cane Sugar Refiners Association was asked whether the refiners had not earlier supported legislation. The response was:

"Yes and of course that was prior to the new HFCS technology which completely changes it. It is an entirely different ballgame..." (Senate Hearings, P. 140). Simultaneously, the Sugar Users Group advocated joining the International Sugar Association with deficiency payments to growers if the price fell out of the International Sugar Association Range. This would have permitted sugar prices to industrial users and consuners to move with the international price and have supported farmers' incomes. The Sugar Users Group further opposed quotas, and adrocated fees on imports, if necessary, rather than quotas. Thus, by 1978, with the increasing competition from HFCS (see Table 2), the unanimity of interests represented by growers, processors, refiners and users broke down completely. In these circumstances, the administration decided to have the United States join the International Sugar Organization as its proposed assistance to domestic sugar interests. ${ }^{36}$

36. The United States did join the International Sugar Organization, which set 13 to 23 cents per pound raw value as its target price range. As can be seen from Table 1, the ISA was unable to prevent the price from exceeding this 
Although action was proposed repeatedly in the mid-1970s as the world price of sugar fell, no bill passed in those years. In 1978 and 1979, price supports were put into effect under general agricultural legislation, but in the following two years, the world price of sugar (see Table 1) once again soared, rising froin 9.66 cents per pound in 1979 to 41.09 cents per pound in October 1980, and then falling almost as precipitously to 16.32 cents per pound by July 1981.37

7. The Sugar Program of the 1980s.

It was while the price of sugar was high that a new sugar program was passed. Unlike earlier measures, however, the sugar program was treated as part of the overall Agriculture and Food Act of 1981 , rather than as a separate piece of legislation. The new program set domestic price support levels for the period 1982 to 1985, with an interim support level until March 1982 of 16.75 cents per pound.38 No quotas were set on imports, as it was an-

range during 1980-81 and could not prevent its fall below the target range in 1982 .

37. Data are from Terpstra, P. 4

38. The Administration had not advocated a support price for sugar, but apparently accepted it in return for support for other legislation, probably in part because it was not anticipated that the world sugar price would fall so drastically or so soon. The Senate had passed a support bill, at an initial price of

16.50 cents a pound; the House had rejected an amendment that would have made the price 18 cents a pound for the 1982 crop, and had then voted down the program. But sugar price supports were passed as part of the 1981 farm program after the particulars had been worked out in conference committee. Loans until the end of March 1982 were to be made at the rate of 16.75 cents per pound raw basis and 19.70 cents per pound of refined beet sugar. The Secretary of Agriculture was instructed to set the price for the 1982 crop at a level not less than 17 cents a pound, for the 1983 crop at 17.5 cents a pound, at 17.75 cents for 1984 and at 18.00 cents for 1985. Growers could get a loan at these prices from the $\mathrm{CCC}$, and decide not to reclaim their produce, which in effect meant that they would repay only if the price rose above the support level. The CCC cannot sell commodities it is holding at less than 1.05 times the purchase price. 
ticipated that the support price could be maintained by altering the tariff and fee applicable to sugar imports (which the President was authorized to do under existing legislation). It was anticipated that the purchase price would not be attractive relative to the world price, and that the domestic price could be adequately supported through import duties and fees. ${ }^{39}$ One aneridment to the bill, which was adopted, prohibited the financing of the sugar program from government revenue sources. Thus, the CCC could not buy sugar that would not be repurchased by farmers, for it would have had to take a loss to do so.

Once the law was passed, a number of inarket reactions enused. There were unusually large inports at the end of 1981 in anticipation of the higher tariffs that would be inposed.40 Also, by late May, the Department of Agriculture had to issue regulations that a sugar processor could not sell more to the government than the minimum he had had on hand over the preceeding sixmonth interval. A Washington Post article suggested that sugar processors had deposited more sugar with the CCC than they in fact had with the intent of forcing the governmert to impose quotas.41

As the sugar price fell on world markets, it became apparent that the Commodity Credit Corporation would end up holding some sugar that it had received from famers in return for "loans". The tariff had already been increased to the maximum extent permissible by law $(50$ percent of the world price). As the world price fell, (see Table l) it became evident that maintenance of the support prices mandated by the 1981 law would not be possible without CCC purchases of crops that would not be repurchased by growers unless other action was taken. Since CCC retention was inconsistent with the amend-

39. See Terpstra, 1982.

40. See Terpstra, 1932, P. 8.

41. Washington Post, June 6, 1982. 
ment requiring no budgetary cost from the program, something had to be done. In :hy, emergency quarterly import quotas were established on a country-bycountry basis to avoid a "loss to the Treasury".12

At that time, it was estimated that the "cost of production" of sugar was about 21-22 cents per pound in the United States. Production was decreasing in llawaii and in sugarbeet growing areas, and mills were in fact closing down. There were no production ceilings on any U.S. source.43

Import quotas were established on the basis of average deliveries over the preceeding years when entry had been free. This was done to attempt to insure conformity with the nondiscriminatory clauses of GATT pertaining to the imposition of quotas.14

As can be seen from the price disparities in Table 1, the divergence between American sugar prices and world prices were now so great that difficulties were bound to ensue. From the raw sugar (cane) refiners' viewpoint, a major difficulty was that quarterly quotas prevented any futures contracts.

42. One of the precipitating factors blamed by the administration for its inability to inaintain the domestic sugar price at the legally mandated level without CCC purchases was the fact that some sugar was being imported under the Generalized System of Preferences, under which some developing countries were permitted to export to the U.S. at less than normal duty rates. Since most sugar imports came from developing countries, the GSP legislation undermined the effectiveness of the tariff. The Administration also pointed to the European Community sugar policy as a source of excess supply on the forld market, and hence of the declining world price. Later on, a similar policy dilema arose between the Caribbean Basin Initiative and sugar price supports.

43. See Terpstra, 1982, P. 10

44. Until 1974, the United States could impose quotas legally under GATT because its agricultural legislation had been in effect from GATT's initiation and had therefore been subject to "grandfathering". However, quotas had to be nondiscriminatory to qualify when they were reinposed in 1981, as grandfathering no longer applied. When American policy toward Nicaragua shifted, the Administration eliminated the Nicaraguan sugar quota. Nicaragua sued the united States in the International Court of Law and won its case, although the United States failed to provide redress. 
They therefore the Goverment before the U.S. Court of International Trade. The court, however, ruled in favor of the U. S. government, so quarterly import quotas persisted. ${ }^{45}$

At least six Presidential proclamations had to be issued between 1982 and 1983 to attempt to contain the side effects. Among the inore interesting was the effects on trade with Canada. Canada had no protection on sugar and imported it at world prices. The Canadians at first added 6 percent corn syrup to sugar, since anything less than 94 percent sugar was not "sugar" from the viewpoint of the regulations. This was then shipped to northern U.S. points and sold to U.S. producers of sugar-containing products. When these shipments reached 175 thousand tons a jear, they were banned. Then, Canadian firms began producing high-sugar content calse mixes and other products, which were exported to the United States where, once again, the sugar was extracted. Canadians firms also shipped sugar into the U.S. as "packets of cocoa and tins of maple syrup and in Aunt Hetty's Patent Pancake Mix" (quoted from the Economist, cited below). These, too, were banned. However, other countries' exports of sweet products to the U. S. also rose, so that by January 1985 emergency import quotas were placed on all imports of sweetened cocoa, cake mixes and edible preparations. This latter category was filled by March 5, 1985, meaning that no korean noodles (.002 percent sugar), kosher pizzas, or other products with any sugar could be imported for the remainder of the year.46 import prohibitions were put on all sugar-containing products after these, and other, responses to the price differential had been felt. Noteworthy were the

45. Terpstra, 1982, P. 15

46. See Economist, June 1, 1985, P. 31 of American Survey. 
protests of candy producers, after imports of confectionary products rose from 39,850 tons in 1980 to 95,553 metric tons in 1985: candy producers had been part of the Users' Group which earlier had supported the sugar program.47

Data in Tables 1 to 3 tell the story thereafter. Support prices were set, and import quotas established at levels designed to achieve them. However, the substitutability of HFCS was so great that sugar consumption began declining precipitously. All American soft drink bottlers shifted to HFCS by 1985. Sugar accounted for less than half of all saloric sweetener consumption by 1985, when its price had risen to 5 times the world price.

By 1987, U.S. imports had fallen to an estimated 1.48 million tons of raw sugar, down from 5 million tons as recently as 1979 and 1981 . Estinates of the total cost of sugar support ranged from $\$ 800$ million to $\$ 2.5$ billion, depending on the estimated world price in the absence of the program, with payments per sugar farm estimated to be $\$ 136,000$. More than half of all caloric sweetener consumption was now high fructose corn syrup, and the proportion continued to increase. Moreover, in 1987, it was announced that a technique for making crystalline dry corn sweetener had been discovered.

On existing trends, it is expected that the United States will stop importing sugar in either 1988 or 1989. As earlier mentioned, import quotas for 1988 have been set at 750,000 tons, half the 1986 level. When there are no longer any imports the policy choices available to the politicians will change and their costs will rise. If sugar prices are to be maintained at their present

47. See U.S. D.A., Foreign Agricultural Circular, Sugar, Molasses and Honey, FS 2-86, November 1986, Pp. 18-24 for a listing of the 113 significant proclamations, Presidential signatures, notices filed, and USDA announcements pertaining to sugar over the 1982-E.5 period. See also Council of Economic Advisers, Economic Report of the President, 1987, P. 165. 
levels, either stocks will have to mount or subsidized exports will have to start. If the political process is unwilling to accept either of these two options, price supports will have to be lowered.48

\section{The Political Economy of the Sugar Program}

No case can ever prove a rule, and the sugar program is no exception. Like everything else, sugar is unique, and its uniqueness has undoubtedly influenced the evolution of intervention in the sugar market over the years. Nonetheless, one can ask certain questions which pertain to the various models outlined in Sect. 1, and venture hypotheses as to some missing ingredients. Questions which may shed light on the appropriateness of the competing underlying models include: 1) who gained and who lost under the sugar program? 2) did all parties act rationally in their own self-interest?; and 3). to what extent does the conservative social welfare function model, the Becker model, the Brock-Magee trade-off model between votes and lobbyists, the Olson freerider model, or the Bhagwati-Srinivasan revenue seeking approach capture the essentials of sugar controls? The answer to the third question really points

48. This section was written in December 1987. On January 7, 1988, the New Yorl Times , under the headline "Buried in Spending Law" reported that Senator Inouye (Hawaii), with the "backing of domestic cane and beet sugar growers", had succeeded in getting a little-noticed provision into the $\$ 600$ billion spending bill to permit an addition 400,000 tons of sugar - in addition to the 750,000 quota - imports into the United States in 1988 "to offset the impact on foreign producers of drastic cuts in American sugar imports in recent years." The additional 400,000 tons, allocated to the Caribbean and the Philippines, is to be imported at American prices, refined, and may not be sold in the United States, i.e., it must be reexported at world prices. The 1980 Onnibus spending bill allotted $\$ 100,000,000$ million to cover the financial loss under this program, equal to 12 cents per pound). Obviously, this additional sugar will increase the capacity utilization rate in domestic sugar refineries. The New York Times was silent on the issue of how the additional imported cane would be allocated between refineries. It would therefore appear that the final paragraph of this section was too optimistic: a new instrument has been created under which the United States can import raw sugar and reexport that, which will make it relatively straightforward to reexport domestic surpluses when domestic production exceeds consumption. 
to some missing elements in existing models which may be important for understanding political controls over economic activity. These include importantly: 4) institutional bottlenecks to achieving a Pareto-superior solution; 5) the interaction between economic markets and political markets?; and 6) the role of knowledge, and of technocracy, in influencing controls. These issues are considered in turn in this section.

\subsection{Who Gained and tho Lost?}

All the available evidence suggests that most American sugar land earns no more than it would in alternative uses. The only possible exception is Hawaii, which will be discussed further below. Even with the relatively high sugar prices of recent years, there has been little expansion of acreage devoted to cane and actual contraction of acreage devoted to beet.

Moreover, this does not appear to be an entirely new situation. In 1974, Johnson concluded that the sugar program was an "evil system, costing between $\$ 500$ and $\$ 730$ million, depending on whether the premiun per pound was 1.5 or 2.5 cents(Johnson, p.50). This contrasted with gross farm income from sugar at that time of about $\$ 870$ million. 4

Johnson estimated that the average income per sugar farm in 1972 was $\$ 619,356$ in Florida, $\$ 312,611$ in Hawaii, $\$ 75,089$ in Louisiana, and above $\$ 30,000$ in all sugar-producing states except Puerto Rico, Colorado, Montana, Nebraska, Utah, Michigan, and Ohio. There were altogether 175 thousand produc-

49. Johnson, Pp. 54-55. Johnson's estimates excluded Puerto Rican and Hawailan-grown sugar. They were based on the assumption of a 2 cent a pound quota premium in addition to the tariff. Taussig believed that no mainland acreage was profitable for sugar, given alternative uses, and attributed the development of sugarcane acreage in Louisiana to American protection in the nineteenth century. See Taussig,1915, Ch. IV. 
tion workers in 19il, but their average hourly earuings (both in growing and processing) were significantly below the average for persons with comparable training and skills in each state.

Johnson concluded that

"...the net benefits - the net increase in income going to farm-owned resources - are only a small fraction of the gross benefits. Most of the gross transfer's are required because the U.S. is a high-cost producer of sugar. Many resources are used in sugar production that would readily find employment elsewhere...Much of the gross transfer is required to induce these resources to be devoted to sugar production rather than their next best aiternative...(Johnson, P. 58).

Turning to analyze beet and cane separately, Johnson found no evidence that the price of sugar beet land (near mills) was significantly different than the pricing of other land in beet growing areas. He notes that:

"I must admit that these results surprised me. I had expected to find some positive effect.. There has been considerable political pressure to establish new sugar beet producing areas, and it seemed reasonable to assume that Exwiners expected to gain from these efforts..."(P. 61) of the six new beet processing plants established after 1962, 2 (New York and Maine) were "complete failures" (because they could not obtain enough sugar beets to operate). The acreage allotted to sugarbeets in Arizona had been only half that anticipated when the plant was built (P. 61). Moreover, the Secretary of Agriculture had not, at that time or since, had to impose "proportionate allotments" on any producing area since 1966.

As for cane, Puerto Rican production and acreage had been declining for a decade at the time of Johrison's analysis. For Hawaii, most benefits went to the large producers, as noted above, as 25 out of the 705 sugar farms produced 93 percent of the sugar.50 In addition, field worker wages in Hawaii were 
double the national average and Johnson concluded that "it is quite possible that some of the economic rent from sugar production in Hawaii has been captured by approximately 5,000 farm workers."(p. 67)51

During the 1970s, wrore beet and cane processing plants went bankrupt.USDA data show 58 beet processing factories operating in 1970, 56 operating in 1975,43 operating in 1980, and 36 operating in 1986. There were 75 sugar mills processing cane in 1970, and the number fell to 42 by 1986.52

Certainly, refiners of inported raw cane sugar lost from the sugar program, at least starting with 1970 and the increased inroads of HFCS. Some went bankrupt, and the total demand for their product fell sharply as beet and sugar substitutes replaced imported raw cane sugar.

There is little reason to question Jolnson's conclusions today. Indeed, subsequent bankruptcies, the failure of the industry to expand despite greater protection and higher prices relative to some other crops, all suggest that most of the cost of the sugar program was absorbed by the excess cost of production. Indeed, even the argument first put forth in 1934 -- that the United States should have some domestic production capability in the event that foreign supplies were disrupted ---no longer seems compelling in light of the HFCS substitution possibilities.53

50. Johnson noted the disappearance of data on size of sugar farms in Hawaii from the Census of Agriculture starting in 1969 (Johnson, P. 66).

51. Taussig, 1915, pointed to immigrant workers as the chief gainers in Hawaii from sugar protection, asserting that native Hawailans, like native Americans, would not work in cane fields. Taussig, 1915, Ch. 5, P. 65.

52. See Sugar and Sweeteners outlook and Situation, June 1987, Tables 19 and 20. Total sugar capacity remained approximately constant as those mills still producing were handling larger average volumes.

53. And if concern had genuinely been over the adequacy of foreign supplies, one wonders why distant, landlocked Subsaharan African countries should have a quota. 
If there were gainer's, they would have been Hawailan growers (who are lowcost relative to the mainland). But there, strong unions apparently appropriated most of the rents from higher sugar prices for the plantation workers, who therefore were the chief Hawailan gainers. Since most workers are inmigrants, they should not have a significant political voice.54 It is interesting to speculate on the type of political-market model that would yield an outcome in which the chief gains from controls had no voice or vote in the decisions to adopt those controls.

\subsection{The Rationality of the Actors}

Ore of the fundamental assunptions of economists is that individuals are $r^{2}$ ational in their own self interest. Even with individual rationality, of course, a group does not necessarily maximize as models of the prisoners' dilemna readily demonstrate.

There are two issues here. First, how well did the representatives of the rarious interests (cane and beet growers, cane millers, beet refiners, and raw cane sugar refiners) know their own interests? Second, was the collective outcome rational, in the sense that policies could have been devised that rendered all concerned better off?

In the same way that more alternatives are always preferable to fewer, there must have been short-run gains to those already growing sugar, or with the possibility of growing beet or cane, from the sugar program at most points in time. That does not, of course, prove that the gains were maximized. For example, had the sugar program in 1981 been established to provide deficiency payments to farmers (compensating for the difference bewtween the price

54. Taussig noted this same apparent anomoly, that immigrant workeres were the chief beneficiaries, in his analysis of the sugar program. At that time, he concluded that the refiners had also gained, at least temporarily, through their fornation of the trust. 
received by them and a target support price), HFCS could not have made the inroads it did on sweetener consumption. Although one can point to this policy instmment as being clearly superior on economic grounds in the long run to support prices in the presence of the HFCS alternative, one can still claim rationality for the sugar interests IF it is claimed that they feared the transparency of deficiency payments.

If, however, there is a need for obscurity in programs such as American sugar, then the role of lnowledge becones important, since to assert a need for obscurity is equivalent to asserting the necessity of hiding what is in fact happening. 53 .

Moreover, even then, it seems apparent that many of the gains of the sugar progran prior to the 1970s did not go to American interests: many foreign countries were gainers.56 Certainly there was considerable political opposition aroused by the activities of foreign lobbyists, especially in 1962 when they were widely blamed for having achieved the 1962 reimposition of country-specific quotas.57 One might have thought the domestic sugar interests

55. See Sect. 8.6 below. There is also a question as to why attempts were not made to prohibit HFCS. While this relates to the transparency issues as well, other factors were also involved. See below for a discussion.

56. They did not gain by the full amount of the premium times their quota, of course and some with small quotas into the American market probably lost. For most countries, sugar was sold both to the United States at premium prices and on the residual world market at much lower prices. To the (considerable) extent that the world price would have been higher in the absence of American quotas, only those sugar exporters gained whose quantity exported to the United States times the premium exceeded the quantity they exported to the rest of the world times the amount by which the world price was below its nosugar-program level. However, it was not until 1985 that any foreign representative in Washington publicly opposed the program.

57. See Berman and Heineman. Since focus here is on domestic economicpolitical interactions, many of the irrationalities involved in the allocation of foreign sugar quotas are ignored here. Suffice it to note that the Dominican Repulbic under Trujillo was the big gainer from the 1962 legislation at a time when the Administration was attempting to impose sanctions on the regime. Berman and Heineman's comment was that "It is not easy to find rational justification for many of the quotas that were recommended by the House Agriculture Committee and included with little change in the final 
would have disassociated themselves from the foreign interests, yet that does not appear to have happened.

Furthermore, there are a number of actions that were NOT taken that would have been rational, if one accepts the viewpoint that the overall program was beneficial to sugar interests.5\% To cite just a few: If large Hawaiiar growers really profited from the progran, one would have expected them to be sufficiently rational to support a price ceiling in 1974 , rather than to permit the opposition that arose to the very high (and very temporary) price of sugar to defeat the entire progran; 2). why did the sugar interests accede to American efforts to support the International Sugar Organization in the late 1970s rather than push for more effective action?; 3) why in the early 1960s did the sugar interests so adanantly support country-specific quotas, when they could have bargained for a larger domestic fraction of the market with a global quota?

Then, too, there is a list of positive mistakes if one takes a narrow, short-run, self-interest model and accepts that the sugar program did help American sugar over the short run. There seems little doubt that many of the large growers were among those most adamantly opposed to the program in 1934, although they did reverse sides by 1937.59 There is also the question of why

legislation." (P. 425). They proceeded to cite a quota of 15,000 tons for Panama (which had produced only 5000 tons a year) and several other countries which could not meet their quota, as well as quotas for the Netherlands and Ireland (although a separate provision of the bill prohibited imports from countries that themselves imported sugar as these latter two countries do).

58. There is abundant evidence worldwide that protection of domestic industries tends to weaken their competitive abilities and thus render them even higher cost and more uncompetitive in the long run than they are when protection is first introduced. It is certainly conceivable that that has happened to American sugar. While it is unarguable that some sugar land has such good alternatives that it is inherently uncompetitive at any plausible world price of sugar, it is also possible that some lands, such as the Hawaiian, might have been considerably lower cost producers had they been subject to foreign competition.

59. See, for example, Krauss and Alexander, 1965, Pp.336. 
soft drink bottlers, cake mix manufacturers, bakers, and confectioners were so willing to support the program. Finally, the support of the sugar refiners was clearly essential for the continuation of the program and yet was obviously ruinous to them in the long run.

Finally, in the large, there have clearly been a number of actions which could at best have been very short-term maximization. Given that the United States will shortly stop importing sugar altogether, and that high fructose corn syrup and crystalline fructose corn can be expected to continue to take an increasing share of the market (along with non-caloric or low-caloric sweeteners which are better able to compete at higher sugar prices) it is interesting to ask whether the sugar program has even been in the long-run interests of Hawaiian and other low-cost growers.

Moreover, there seems to have been no effort to bring HFCS under regulation to prevent its emergence as a substitute for sugar. Certainly if it was rational to seek a high domestic sugar price, the sugar producers should have sought a ban on high fructose corn syrup, or if not that, at least a system of deficiency payments rather than price-raising measures. The declining consumption of sugar in the United States, and the increasingly competitive position of corn substitutes were clearly not consistent with the longer-term interests of sugar producers, and even less so of refiners. Had sugar growers and refiners been willing to accept a deficiency payment program in the late 1960s (so that payments to growers would compensate for any divergence between the world price-plus-margins and the domestic support price), much of the HCFS competition would have been avoided.60

60. The representatives of the corn refiners were at pains to assure Congress that their costs were high, and that "sugar is still the standard of the sweetener industry." (Testimony of Donald E. Nurdlund, Chairman of A. E. Staley Mantifacturing Co., representing the corn producers, at 1978 House Hearings, P. 138 
At present, the corn producers strongly oppose any switch to deficiency paynents on the grounds that they would provide "unfair competition" to corn in the sweetener market. Indeed, Congressional representatives from cornproducing states now appear to be the strongest supporters of the sugar program, including import quotas. Whether that support group would have developed had sugar producers correctly estimated the potential competition from corn is an open question. Certainly, to the extent that corn producers are the gainers from the sugar progran, there is no evidence of their apparent support for the progran prior to the 1970s.

The apparent reason for the sugar growers' opposition to deficiency payments seems to have been their concern that a ceiling would be placed on the size of the payment that might be made to any individual farm. This in itself suggests that growers were sensitive to the degree to which benefits went to larger farmers, but it does not indicate why refiners and processors were willing to support import and production quotas.61

Even beyond that, however, there lies the question--alluded to by Johnson - as to why in the early 1960s it was anticipated that there would be great benefits to expanded beetsugar production. These do not seem to have been forthcoming, and the evidence strongly suggests that such an expansion was not in the interests of existing producers and did not significantly benefit those in areas where new beetsugar mills were established.

61. For an amusing sidelight to the story, see the testimony of Helen Rohrbaugh, Head,Quota Section, Special Operations Branch, Office of Operations, U.S. Customs Service. This branch is (or at least was in 1974) in charge of administering all import quotas. Ms. Rohrbach explained why her branch could not administer import quotas (which were set in raw value terms) as then currently laid down: Congressman Vigorito, who presided at the hearings, thanked her for her testimony with the statement: "You have brought to my attention a small group in Customs that I did not know existed...." (P. 9 ? of 1974 hearings) 
If one is to believe statements from representatives of the sugar interests, sugar producers have not been happy with the program. According to the Economist after the 1985 bill was passed:

"...It might be supposed that the sugar-growers, at least, would be happy with the absurd press for regulations. They are not. They get a government subsidy of 17 cents a pound, but say it costs them 20 cents to produce one. Acreage under sugar cane in Florida, Louisiana and Hawaii, or under sugar beet in the inidwest, continues to contract... Economist, June 1, 1985, P. 31 of American survey.

There is then the curious episode with the International Sugar Association: the ISA could not contain the price of sugar even within a very wide band. In part this was because the EC did not join. However, it is difficult to imagine that, even with EC participation, the target range could have been maintained without resources considerably in excess of those available to the ISA. It is difficult to believe that the ISA was expected to be effective in stabilizing the sugar price: why, then, was support for ISA membership talien as an acceptable substitute by the sugar producers for a sugar program?

Next, there is an interesting question as to why some arguments are convincing, or are thought convincing, in the political arena. Virtually all witnesses to Congressional hearings on the sugar program listed as one of its major virtues the fact that "it costs the taxpayer nothing".62

62. See, for example, the statement contained in the House Agriculture Committee pamphlet on the U.S. Sugar Program (1971): "The Sugar Act has given us this security of supplies at a reasonable cost to the consumer and at no cost to the taxpayer..."P.45. Note, however, that the decision to permit the import and reexport of 400,000 tons of sugar in the onnibus spending bill passed by Congress in December 1987 invalidates this argument, and of course sets a precedent for subsidies to support exports in future years. 
A second oft-repeated argument pertained to the alleged instability of the international sugar market and the "need" for price stability for producers. This argument first appeared in Roosevelt's message to Congress in 1934, and was reiterated by almost all witnesses supporting the Sugar Program. Yet the program was neither designed for "stability" (since there was no ceiling) nor were there efforts to set a "band" within which the price might fluctuate. Whether it was thought that appeals for "stability" were more convincing than appeals for support prices is open to conjecture, but the inconsistecy of rhetoric pertaining to stability with the appeals for higher prices strikes one on even the most casual perusal of Congressional testimony.

A.though a large number of other apparent irrationalities could be pointed to, it suffices to mention one more: surely in 1974 and again in 1981, it should have been understood that the prevailing price of sugar would not continue indefinitely. Even without any degree of sophisticated understanding of the sugar marlet domestically and internationally, all testimony before both houses of Congress had for years emphasized the wide fluctuations in sugar prices as a reason for controls. Yet the Reagan administration apparently believed that it had a sugar program which would not require a return to the country-specific quotas that had earlier prevailed.

\subsection{Goodness of Fit of Existing Political Economy Models}

Without doubt, the saga of the American sugar oorigran over the 1934-1987 period contains elements of a number of the models discussed in sect.1. There is very little of the "benevolent guardian, social-welfare maximizing" governmerit in the story, however, and that model fails, at least after 1934 .

Clearly lobbying was important, as the various components of the sugar industry sought to increase the benefits they perceived as emanating from the bill and foreign lobbyists did the same thing for their clients. Becker's 
model and the Brock-Magee approach both have significant elements of truth, at least in analyzing the sugar program and its evolution. There are, however, a number of phenomena which are not captured in these models, to which attention returns in Sects. 8.4 to 8.6 .

An interesting point to note with respect to lobbying models, however, is that they do not fit Olson's prediction that interest groups would form when the group on the opposite side of the market consists of relativly small and fragmented entities. Sugar user's were at least as large as sugar producers and nonetheless joined in the coalition. One would not have forecast the coalition of interests that did emerge. There was ultimately a significant conflict between the interests of domestic and foreign growers, between domestic growers and refiners, and between domestic producers and domestic industrial users. These latter were large, which is not normally anticipated in discussions of lobbying.63 The puzzle here is thrown in even sharper relief when it is asked why sugar growers, millers, refiners, and users were all on the same side of the issue when there were clearly some divergent interests among them.

Lobbying, at least by domestic growers, was NOT significant in the inauguration of the sugar program, however. Growers seem actively to have opposed it initially, and it is certain they did not lobby for it. In that respect, the Bhagkati-Srinivasan revenue-seeking model, in which resources are spent in an effort to obtain a program of value, does not seem appropriate for the initiation of the sugar program. Once the program was in place, however, domestic sugar growers rallied to its support. In a sense, the history of the

63. There is no doubt that Americans owned some sources of foreign supply. This was especially true in the 1930s. However, even then, only about a third of Cuban sugar was produced under American ownership. For the Philippines, the fraction did not reach that level until after Philippine preferences were in place, and the mechanism seems to have worked the other way around: the American preference induced American firms to start producing in the Philippines. See U. S. Tariff Commission, 1937 . 
sugar program since 1934 is that a government which regarded itself as a platonic guardian put the program in place with certain short-term goals. The program once in place was perpetuated by the interaction of political and narket forces that could seize upon it. Thus, a program which started out intended to benefit Cuba was nonetheless perpetuated when assisting Cuba was no longer an object of policy. Likewise, country-specific quotas continuedafter the Anerican interest in Cuba subsided, in part because they were lobbied for and supported by powerful groups in Congress which had grown up because the sugar program was there. Even in the 1980s, when sugar interests came to recognize their interest in deficiency payments rather than price supports, corn interests emerged to defend the program.

The conservative social welfare function argunent reasonably well fits the motive for introduction of the sugar program in 1934; it does not explain its reintroduction in 1948 , its continuation of country-specific quotas after 1960, nor the evolution of the program thereafter.

Thus, there is no doubt that economic interests and lobbying go part way toward explaining the sugar program. There are missing elements, however, to which attention turns below. First, it is apparent that institutional mechanisms fere necessary in order to facilitate the continuation of the program, and that alternative arrangements might have reduced the economic costs of the program, even if they would not have eliminated it. Secondly, it is clear that markets reacted to the various shifts and turns in policy in ways which neither politicians nor sugar interests anticipated. In this sense, there never was "the" sugar program; rather, policies evolved over time as politicians reacted to market responses (and exogenous events) and markets reacted to the changes in policy. Finally, any reading of the evolution of 
sugar policies over time suggests that a number of key issues surrounding transparency, lnowledge, and the role of technocrats must be addressed. It is to these nissing ingredients that attention now turns.

\subsection{Institutional Issues}

Several institutional issues are noteworthy. First, there is the anomaly (for the American Congress) that sugar legislation was handled by the Senate Finance Committee (because it is an import) and the House Agriculture Committee (by historical accident). Moreover, because it was an import and thus had revenue implications, only the House had the power to initiate legislation. This gave the House Agriculture Committee considerably more power over sugar than it would have had had the counterpart body been the Senate Agriculture Comnittee, and the House Agriculture Comnittee had considerably more ability to focus its attention on sugar than would the House Ways and Means omnittee. 64

Second, the sugar program could not have persisted in anything like the form that it did had sugar not been an import. At a minimum, there would have been a budgetary cost to any program which raised price. As mentioned above, the "lack of budgetary cost" was frequently mentioned as an important point by advocates of the program. Likewise, because sugar was an import, the program provided instrunents of foreign policy (the sugar quotas) which would otherwise not have been present. Moreover, had sugar not been an import, it fould

64. Had the House Ways and Means Committee handled the legislation, its attention would have been spread over enough other issues that it could not have devoted as much tine to it as did the House Agriculture Committee. Moreover, membership on the House Ways and Means Committee would have been determined with respect to many more issues and thus could not have been as specialized as was the House Agriculture Committee. For a discussion of these issues, see Price. 
have been dealt with together with other agricultural comnodities: it is likely that the ability of sugar interests to influence the outcome (for better or worse in their onn self interest) would have been less.65

Indeed, it is arguable that it was the ability of the sugar interests to distance thenselves from other elements of a political situation that was crucial to the continuation of the program: it was an import, and therefore came before the Serate Finance Comnittee and was not dealt with as part of other agricultural legislation. While an import, it was agricultural, and thus not dealt with in other trade legislation along with other importable commodities.

Third, it took the agreement of all producing interests - beet growers, cane growers, beet refiners, cane millers, and cane refiners - to insure the continuation of the program. Indeed, until the mid 1970s, what is remarkable is that the Sugar Users Group did not oppose the program.

Fourth, the fact that the interrelationships were complex undoubtedly increased the political influence of those who did understand the economics and politics of the sugar program: in a sense, the complexity of the issues stood as a barrier to entry of nonspecialists. 66

\subsection{Interaction of Economic and Political Markets}

65. The above paragraph was written prior to the passage of the 1987 omnibus spending bill. That bill sets a precedent for expenditures on supporting sugar prices that may ease the way for subsidy payments when sugar is no longer imported. Even so, one might guess that pressures against sugar will mount when the program must be financed from the budget.

66. In some hearings late in 1974 after the defeat of the Sugar Program, a number of witnesses were called. The first was a Mr. Arthur Calcagnini, Director of the Sugar Division, USDA. He was carefully examined on his move from Amerop Corp., international sugar dealers, to USDA which had taken place earlier in 1974. Other witnesses included: Mr. Thomas O. Murphy, the USDA Sugar Division Director from 1963 to 1972, who was in 1974 President, Linited States Sugar Beet Association; and Mr. Lawrence Myers, who had been USDA Sugar Divisioin Director from 1948 to 1963 , and who was a "consultant in agricultural economics and economic adviser to the Philippine Sugar Institute." (P. 81). See also Sect. 8.6 below 
Exanination of the history of the sugar program strongly suggests that, once created, a policy instrument will: 1) be seized upon by groups who perceive themselves to benefit (regardless of whether they had anything to do with initiating the program or not); 2) induce economic market reactions which will minimize the costs of the progran; 3) lead to political responses to (2) by the groups formed under (1) to attempt to offset these economic market reactions, which in turn will lead to 4) increasingly complex policy instruments designed both to deal with the competing interest groups that form around the policy instrument and simultaneously to subvert the sorts of market responses perceived to be detrimental.

This sequence, which as articulated, sounds very straightforward, is perhaps the most obvious, but also the most complex, of conclusions. For it suggests that, once an instrument is in place, a variety of political forces will emerge that will act upon it and try to seize it in ways that are largely unpredictable. In the case of the U.S. Sugar Program, the instrunent was initially opposed by the sugar producers, but they very quickly reversed their position and supported its continuation. Likewise, the sugar exporting countries strongly supported the program until the mid-1980s, and then reversed their position in response to the market forces set in motion by the price support progran.

Ironically in 1948, it was a perceived obligation to Cuba, rather than any motivation of domestic producers that led to the reinstatement of the program. During the years 1948 to 1960 , Congressmen dealing with the sugar program were regarded virtually as foreign agents - their interests appear to have been primarily in allocating import quotas rather than benefitting domestic interests. 
There are tro interesting mental experiments that can be performed: 1) what would have happened had the Cuban goverrment not changed? and 2) what would have happened if there had been no sugar progran prior to 1960 when the Cuban government changed? In answer to the first, the most reasonable conjecture would appear to be that the U.S. sugar program would have continued, much as before, and that there never would have been the expansion of beet acreage and other high-cost (and possibly even ill-advised on the part of those who undertook them) and beet refining capacity that characterized the $1960 \mathrm{~s}$. It is hard to imagine the inpetus that would have been necessary to substantially increase American acreage at the expense of imports.

With regard to the sccond question, had there veen no sugar program in 1960, the most likcly outcome probably is that the United states would have continued buying sugar on world marlsets. It is difficult to imagine a sequence of events under which a changed Cuban government could have been seized upon as a rationale for the Inauguration of a Sugar Program.

Insofar as these conjectures are plausible, they strongly suggest that it is much easier to adapt, or seize, an already-existing instrument, than it is to have a new one created. For that reason alone, an existing instrunent is very likely to becone used for objectives and by groups that may not have been the intended beneficiaries at all wher the instrument was first formed.

There is then the question of narket reaction. Clearly, the market will minimize the cost of any given policy-imposed distortion. In the case of sugar, this entailed two important reactions and several minor ones. The first important reaction was the shift in the location of production (with expansion of Florida land and reduction in beet land). The second was the development of substitutes and with it, the potential disappearance of sugar as an importable good: that will make the Sugar Program, in its present form (with a legislated mandate to avoid any payments by the U.S. government), in- 
feasible. Absent a legal ban on development of all substitutes, it is difficult to see how the political process can further increase the real price of sugar, especially as and if crystalline corn sugar becomes economic. In the longer term, this market reaction to the sugar program may indeed threaten the economic viability of the entire sugar industry in the United States - thereby doing the very thing that muny supporters of the sugar program claimed they vere trying to avoid.

The minor reactions include the importation of soft drinlss, calre mixes, and other sugar-containing products from Canada and elsewhere, the need for detailed regulation of imports to avoid storage costs for American refiners, the seicure of the program by sugar refiners as a basis on which to press for a ben on imported raw sugar or of refined beet sugar, and the diplomatic and other complications arising out of establishing and inplementing import quotas for a large number of countries. An interesting reaction, difficult to classify, has been the increased volatility of the international sugar price in response to the snaller and smaller volume of transactions going through the "free market" (which would more appropriately be termed the"residual" market).

These market reactions in turn have induced political responses: bans on imports of calie mixes, and then of processed food products containing sugar; movement from annual to quarterly import quotas; reactions to the high sugar price of the early 1970s (which itself was arguably the outconte of the earlier decision to increase domestic production, which depressed the world price, leading to amplified fluctuations in plantings and in sugar price cycles) which led to the (temporary) abandonment of the program, and so on.

In a sense, this "life of its own" hypothesis is the most disturbing for potential economist-policymakers. If the hypothesis is correct, it says that even if a program is designed to meet socially-desirable objectives in cost- 
minimizing ways, it will likely be seized upon by groups and in circunstances only renotely related to the initial intent of the program. Once put in place, a policy may evolve in ways unrelated to the initial purpose. 67

\subsection{Role of linowledge and technucrats}

Partly because of the interaction of economic and political markets, any ongoing progran is likely to become very complex. While sugar may be especially so, it is at least arguable that other agricultural commolities, imports subject to quota, health regulations, and most other policy instrunents inevitably become highly complex. One important consequence is that a coterie of specialists is called for whose human capital consists of their understanding of the program, and hopefully of the economic implications of alternative changes in policies.68

Complexity in and of itself provides a significant barrier to participation of nonspecialist groups in the decision process. In the case of sugar legislation, it seens evident that there were a rumber of efforts to resist changes that might have made the program more transparent: sugar producers opposed deficiency payments (until it was too late) probably because the size of payment per farm would have been apparent and they feared a ceiling; import

67. One needs only to point to the complexity of American income tax laws (even after reform) and of the Multi Fibre Arrangement to convince oneself that the phenomenon is not limited to the sugar case.

68. One indication of the ways in which these interests grow is to examine the length of hearings and the number of witnesses who appeared before the House Agriculture Committee each time the Sugar Act was under consideration. The 1934 Hearings were 251 pages long, with 33 witnesses; in 1937 Hearings were 373 pages long, with 47 witnesses. In 1940, Hearings were 302 pages with 40 witnesses; the 1948 Hearings were short with 114 pages and 10 witnesses; $195 i$ hearings were 323 pages with 46 witnesses and submissions; 1955 Hearings were 768 pages with 136 witnesses and submissions; 1962 Hearings were 552 pages with 81 witnesses and submissions; 1965 Hearings were 365 pages with 74 witnesses and submissions; 1971 hearings were 789 pages with 132 witnesses and submissions. Even this understates the increase, as coalitions of supporters (such as the Sugar User's Group and the Sugar Producers Group) formed. 
quotas were country-specific, rather than global, and there was opposition to any change; inport quotas, rather than tariffs were the chosen instrument for protection; raw sugar refiners supported the program and sought prohibition of imports rather than seeking protection from foreign refiners; and corn producers were adamant in wanting sugar prices supported rather than seeking higher support prices and deficiency payments for corn growers directly.

In addition, however, the specialists in a given policy instrument become a vested interest in the maintenance of SOME policy.69 Those with understanding of the U.S. Sugar Program could seek employment as lobbyists for foreign governments, or as representatives of domestic groups, as Congressional staff assistants, or with the Department of Agriculture. For any nonspecialist to enter the policy dialogue in a meaningful way would require a considerable investment.

All of these phenomena suggest that public discussion of policy options might be significantly inproved if means could be found to lteep policies transparent and simple. The opposition to deficiency payments and other transparent procedures was clearly based on the hypothesis that they would not have withstood careful scrutiny. Whether means can be found in complex markets of limiting the types of interventions that are permitted is a difficult subject, and one well beyond the scope of this essay. Nonetheless, it seems highly likely that, had the Sugar Program been transparent and readily comprehensible to an informed citizenry, it could not have persisted in anything like the form it did.

69. It might be argued that they would prefer some changes because that generates more work, but that issue is secondary. The hypothesis here is that the loss of human capital that would be involved in the complete abandonment of a program is probably so large as to induce specialists to advocate "more rational" programs, rather than program abandonment. 


\section{Sone Tentative Conclusions}

No case study car provide the generalizations desirable to form a basis for a theory of political-economic interactions. The U.S. Sugar Program is, noretheless, interesting in that it raises some questions that are not readily handled with the use of traditional models. Its evclution demonstrates that a static analysis of the costs and benefits of the program at a point in time would significantly misstate the progran's impact: clearly account must be taken of the ways in which econonic and political responses will alter the program over time. It is to be hoped that future research will enable the transformation of some of the questions raised here into testable hypotheses

Several questions clearly call for further research. Anong thein: 1) to what extent are the econonic outcomes of policies reasonably correctly anticipated and to what extent to side effects render the outcomes unacceptable to the policies' advocates?; 2) can one find meaningful characterizations of the logic of interaction between political and economic narliets?; and 3) can one classify policy instruments according to criteria (such as transparency) and then malke meaningful predictions as to, for example, the likely excess cost of policies pursued with each of these instruments?

At this stage, the conclusions that emerge arise primarily with regard to the sugar program itself. First, when it was originally formulated in 1934, and then when it was reinstated in 1948, the intentions of its advocates bore little resemblance to the purposes to which it was put some twenty or thirty years later. Second, it seens highly unlikely that the electorate would support a program that provides payments of over $\$ 136,000$ per farm were that figure highly publicized. Third, at least some of the supporters of the sugar program over the years - the importers and refiners of raw sugar and the beet mills owners who went bankrupt at the very least - would not have been so enthusiastic had they known the outcome. 
At a more general level, two tentative lessons emerge. First, at the very least, economists advocating govermment intervention in markets would be well advised to recognize that the measures they advocate will, once enacted, have a life - including supporters - of its own. Second, in choosing between alternative policy instruments, there should be a strong presumption in favor of simple, transparent instruments: the likelihood that those instruments can be seized in ways unacceptable to a comprehending electorate would be reduced. 
Table 1. New York and World Sugar Frices, 1948-1987

$$
\begin{aligned}
& \text { F.O.B. N.Y. Ratio: } \\
& \text { Caribbean duty- N.Y. to } \\
& \text { (1) paid }(2)^{\text {world }} \text { (3) }
\end{aligned}
$$

$\begin{array}{rrrr}1948 & 1.17 & 5.6 & 1.34 \\ 1949 & 4.34 & 5.8 & 1.34 \\ 1950 & 4.98 & 5.9 & 1.18 \\ 1951 & 5.67 & 6.1 & 1.08 \\ 1952 & 4.17 & 6.3 & 1.51 \\ 1953 & 3.41 & 6.3 & 1.85 \\ 1954 & 3.26 & 6.1 & 1.87 \\ 1955 & 3.24 & 6.0 & 1.85 \\ & & & \\ 1956 & 3.48 & 6.1 & 1.75 \\ 1957 & 5.16 & 6.1 & 1.18 \\ 1958 & 3.50 & 6.3 & 1.80 \\ 1959 & 2.97 & 6.2 & 2.09 \\ 1960 & 3.14 & 6.3 & 2.01 \\ & & & \\ 1961 & 2.91 & 6.4 & 2.20 \\ 1962 & 2.98 & 6.3 & 2.11 \\ 1963 & 8.50 & 8.2 & 0.96 \\ 1964 & 5.87 & 6.9 & 1.18 \\ 1965 & 2.12 & 6.8 & 3.21 \\ 1966 & 1.86 & 7.0 & 3.76 \\ 1967 & 1.99 & 7.3 & 3.67 \\ 1968 & 1.98 & 7.5 & 3.79 \\ 1969 & 3.37 & 7.8 & 2.31 \\ 1970 & 3.75 & 8.1 & 2.16 \\ & & & \\ 1971 & 4.52 & 8.5 & 1.88 \\ 1972 & 7.43 & 9.1 & 1.22 \\ 1973 & 9.61 & 10.3 & 1.07 \\ 1974 & 29.99 & 29.5 & 0.98 \\ 1975 & 20.49 & 22.5 & 1.10 \\ 1976 & 11.58 & 13.3 & 1.15 \\ 1977 & 8.11 & 11.0 & 1.36 \\ 1978 & 7.82 & 13.9 & 1.78 \\ 1979 & 9.66 & 15.6 & 1.61 \\ 1980 & 29.02 & 30.1 & 1.04 \\ & & & \\ 1981 & 16.93 & 19.7 & 1.16 \\ 1982 & 8.42 & 19.9 & 2.36 \\ 1983 & 8.49 & 22.0 & 2.59 \\ 1984 & 5.18 & 21.7 & 4.19 \\ 1985 & 4.04 & 20.3 & 5.02 \\ 1986 & 6.05 & 21.0 & 3.47 \\ 1987 & 7.10 & 21.7 & 3.06\end{array}$

column 1: Caribbean price; column 2: New York duty-paid price; column 3: the ratio of 1 to 2

Source: U. S.Department of Agriculture, Sugar and Sweeteners Situaiion, various issues. 
Table 2.SUGAR AND SWEETENER CONSUMPTION,

UNITED STATES, 1970-1987

$\begin{array}{cllll}\begin{array}{c}\text { Refined } \\ \text { sugar }\end{array} & \text { HFCS } & \begin{array}{l}\text { Total } \\ \text { corn }\end{array} & \begin{array}{c}\text { Total } \\ \text { Sweeteners }\end{array} & \begin{array}{l}\text { Percent Sugar } \\ \text { of Total }\end{array} \\ & \text { (millions of tons) } & & \end{array}$

$\begin{array}{lrrrrr}1970 & 10.43 & 0.07 & 1.98 & 12.57 & 83.0 \\ 1971 & 10.60 & 0.09 & 2.16 & 12.91 & 82.1 \\ 1972 & 10.74 & 0.14 & 2.21 & 13.11 & 81.9 \\ 1973 & 10.68 & 0.22 & 2.48 & 13.31 & 80.2 \\ 1974 & 10.22 & 0.32 & 2.68 & 13.03 & 78.4 \\ 1975 & 9.63 & 0.54 & 2.97 & 12.75 & 75.5 \\ 1976 & 10.18 & 0.78 & 3.24 & 13.56 & 75.0 \\ 1977 & 10.37 & 1.05 & 3.44 & 13.96 & 74.4 \\ 1978 & 10.18 & 1.35 & 3.75 & 14.10 & 71.4 \\ 1979 & 10.05 & 1.67 & 4.09 & 14.30 & 70.2 \\ 1980 & 9.52 & 2.18 & 4.58 & 14.24 & 64.7 \\ 1981 & 9.13 & 2.67 & 5.12 & 14.39 & 63.4 \\ 1982 & 8.56 & 3.10 & 5.60 & 14.31 & 59.8 \\ 1983 & 8.33 & 3.60 & 6.12 & 14.61 & 57.0 \\ 1984 & 8.01 & 4.30 & 6.84 & 15.01 & 53.4 \\ 1985 & 7.58 & 5.39 & 7.96 & 15.70 & 48.2 \\ 1986 & 7.37 & 5.53 & 8.12 & 15.66 & 47.0 \\ 1987 & 7.44 & 5.65 & 8.29 & 15.89 & 46.8\end{array}$

Source: U. S. Department of Agriculture, U.S. Sugar and Sweeteners Situation, June 1987

Note: Noncaloric sweeteners consumption (in sugar equivalent weight) was .59 million tons in 1970 and rose to $2.23 \mathrm{million}$ tons by 1986. 
Table 3. Sugarcane: Raw sugar production by area, 1950-86 crop years.

Crop year

Florida Louisiana Texas Total Hawail Puerto Total

Rico

\begin{tabular}{|c|c|c|c|c|c|c|c|}
\hline & & $(1,00$ & $t$ tor & , raw & ue) & & \\
\hline 1950 & 108 & 456 & --- & 564 & 961 & 1,299 & 2,824 \\
\hline 1951 & 122 & 297 & --- & 419 & 996 & 1,128 & 2,653 \\
\hline 1952 & 154 & 451 & $\rightarrow$ & 605 & 1,020 & 1,372 & 2,997 \\
\hline 1953 & 151 & 481 & -- & 632 & 1,099 & 1,182 & 2,913 \\
\hline 1954 & 132 & 478 & --- & 610 & 1,077 & 1,204 & 2,891 \\
\hline 1955 & 119 & 455 & --- & 574 & 1,140 & 1,166 & 2,880 \\
\hline 1956 & 129 & 432 & --- & 561 & 1,100 & 1,152 & 2,813 \\
\hline 1957 & 136 & 398 & -- & 534 & 1,085 & 990 & 2,609 \\
\hline 1958 & 136 & 443 & --- & 579 & 1,158 & 934 & 2,278 \\
\hline 1959 & 175 & 441 & --- & 616 & 975 & 1,087 & 2,678 \\
\hline 1960 & 160 & 470 & -- & 630 & 936 & 1,019 & 2,585 \\
\hline 1961 & 208 & 650 & -- & 858 & 1,092 & 1,110 & 3,060 \\
\hline 1962 & 380 & 472 & --- & 852 & 1,120 & 1,009 & 2,981 \\
\hline 1963 & 424 & 759 & --- & 1,183 & 1,101 & 989 & 3,273 \\
\hline 1964 & 574 & 573 & --- & 1,147 & 1,179 & 989 & 3,315 \\
\hline 1965 & 554 & 550 & -- & 1,104 & 1,218 & 897 & 3,219 \\
\hline 1966 & 652 & 562 & --- & 1,214 & 1,234 & 883 & 3,331 \\
\hline 1967 & 717 & 740 & -- & 1,457 & 1,191 & 818 & 3,446 \\
\hline 1968 & 546 & 669 & --- & 1,215 & 1,232 & 645 & 3,092 \\
\hline 1969 & 535 & 537 & --- & 1,072 & 1,182 & 483 & 2,737 \\
\hline 1970 & 652 & 602 & --- & 1,254 & 1,162 & 460 & 2,876 \\
\hline 1971 & 635 & 571 & -- & 1,206 & 1,230 & 324 & 2,760 \\
\hline 1972 & 961 & 660 & -- & 1,621 & 1,119 & 298 & 3,038 \\
\hline 1973 & 824 & 558 & 38 & 1,420 & 1,129 & 255 & 2,804 \\
\hline 1974 & 803 & 594 & 74 & 1,471 & 1,041 & 291 & 2,803 \\
\hline 1975 & 1,061 & 640 & 126 & 1,827 & 1,107 & 303 & 3,237 \\
\hline 1976 & 930 & 650 & 94 & 1,674 & 1,050 & 312 & 3,036 \\
\hline 1977 & 894 & 668 & 88 & 1,650 & 1,034 & 267 & 2,951 \\
\hline 1978 & 972 & 550 & 61 & 1,583 & 1,029 & 204 & 2,816 \\
\hline 1979 & 1,047 & 500 & 93 & 1,640 & 1,060 & 193 & 2,893 \\
\hline 1980 & 1,121 & 491 & 93 & 1,705 & 1,023 & 177 & 2,905 \\
\hline 1981 & 963 & 712 & 110 & 1,785 & 1,048 & 153 & 2,986 \\
\hline 1982 & 1,307 & 675 & 98 & 2,080 & 983 & 113 & 3,176 \\
\hline 1983 & 1,223 & 603 & 60 & 1,886 & 1,044 & 100 & 2,799 \\
\hline 1984 & 1,412 & 452 & 81 & 1,945 & 1,062 & 97 & 3,002 \\
\hline 1985 & 1,413 & 532 & 76 & 2,021 & 2,021 & 109 & 3,109 \\
\hline 1986 & 1,382 & 650 & 75 & 2,107 & 1,045 & 95 & 3,426 \\
\hline
\end{tabular}

Source: U.S.D.A. Sugar and Sweetener Situation, October 1986. ---- means no production at that time. 
Becker, Gary S, 1983. "A Theory of Competition Among Pressure Groups for Political Influence", Quarterly Journal of Economics,

August 1983.

Berman, Daniel M. and Heineman, Robert A., 1963. "Lobbying by Foreign Governments on the Sugar Act Amendments of 1962,", Law and Contemporary Problems, vol. 28, No. 2, Spring. Pp. 416-27.

Bhagwati, Jagdish and Srinivasan T.N.,1980. "Revenue Seeking: A Generalization of the Theory of Tariffs, "Journal of Political Economy, Decenber, Vol. 88, No. $6 \mathrm{Pp}$. 1069-87.

Borrell, Brent, Sturgiss, Robert and Wong, Gordon, 1987, "U.S. Sugar Policy Its Effects on the World Sugar Market", paper presented at International Sweetener Colloquium, California, Feb. 1987.

Brock, W.A., and Magee, S. P., 1978, "The Economics of Special Interest Politics: The Case of Tariffs", American Economic Reviek, 68: 246-50.

Buchanan, James M., 1987. "The Constitution of Economic Policy", American Economic Review, June.

Cameron, Laurie A and Berg, Gerald C.,"The U.S. Sugar Program, An Historical Overview", mineo, undated.

Campos, Jose Edgardo L., 1987 A Simple Political Economy Model of Price Supports. Ph. D. Thesis, California Institute of Technology.

Cater, Douglass, 1964. Porver in Washington, Random House, N.Y.

Congressional Quarterly Almanac, 1962. "Congress Again Revises Sugar Quotas", 1962 CQ Almanac, Pp. 127-130.

Congressional Research Service, 1985. "World Sugar Trade and U.S. Sugar Policy", Report No. 85-144, ENR, July 12.

Corden, W. M., 1974. Trade Policy and Economic Welfare, Oxford University Press, Oxford.

Council on Wage and Price Stability, 1975, Staff Report on Sugar Prices, May.

Ferguson, Allen R., undated, "The Sugar Price Support Program", mimeo.

General Accounting office, 1984. "U.S. Sweetener/Sugar Issues and Concerns", GAD/RCED 85-19, November 15, 1984 .

Gerber, David J. 1976, "The United States Sugar Progran: A Study in the Direct Congressional Control of Imports", Journal of Law and Economics, Vol 19 (1), Pp. $103-47$.

Harris, Simon, "Protectionism in the World Sugar Economy Revisited", mimeo. Sao Paulo, 25 June 1985

Johnson, D. Gale, The Sugar Progiam, American Enterprise Institute, 1974. 
Krauss, Bob and Alexander, William P., 1965, Grove Farm Plantation: The Biography of a Hawaiian Sugar Plantation. Pacific Books, Palo Alto

Leu, Gwo-Jiun Mike and Knutson, Ronald D., "U.S. Sugar Policy: Costs, Benefits, Consequences", Paper presented at Western Economic Association, July 1987 .

Maskus, Keith E., 1987. "The International Political Economy of U.S. Sugar Policy in the 1980s", United States Dejartment of State, Bureau of Economic and Business Affairs, Planning and Economic Analysis Staff. WE/87/1.

Mueller, Denris C., 1983. The Political Economy of Growth, Yale University Press, 1983.

Olson, Mancur 1965 The Logic of Collective Action, Harvard University Press, Cambridge, Mass.

Olson, Mancur 1982. The Rise and Fall of Nations: Econonic Growth, Stagflation, and Social Rigidities, Yale Universitiv Press, New Haven, Conn.

Peltzman, Sani, 1976 "Toward a More General Theory of Regulation", Journal of Lais and Economics, XIX, Pp. 211-40.

Price, David E., 1971,"The Politics of Sugar", Review of Politics. Vol. 33, April (pp. 212-231.

Snape, Richard H., 1963, "Some Effects of Protection in the World Sugar Industry", Economica, February

Stigler, George J., 1971. "The Theory of Econonic Regulation", Bell Journal of Economics, Spring, Pp. 3-21.

Tan, C. Suan, 1986. Cuba-USSR Sugar Trade, Commodity Studies and Projections Division, World Bank, Division Working Paper No. 1986-2.,

Tarr, David G. and Morkre, Morris E., Aggregate Costs to the United States of Tariffs and Quotas on Imports, Federal Trade Commission, December 1984.

Taussig, Frank William, 1924 Some Aspects of the Tariff Question, Harrard University Press, Cammbidge, Mass.

Taussig, Frank William, 1931. A Tariff History of the United States, G. F. Putnan's \& Sons, New York and London.

Terpstra, A. Ellen, 1981 "U. S. Sugar Policy and Proposals Since 1974", Congressional Research Service, HD 9100, July 31.

United States Congress, House of Representatives, Committee on Agriculture, Hearings on Sugar Frogram. Cited as House Hearings, with indicated date.

United States Department of Agriculture, 1985. Economics Research Service. "Background to 1985 Sugar Legislation". 
United States House of Representatives, 1974.Subcomittee on Domestic Marketing and Consumer Relations of the Committee on Agriculture, Examination of Sugar Marketing Conditions Since Defeat of Sugar Bill, Dec. 9, 10,11, 12, and 197, 1974. Serial 93-XXX. Referenced as Sugar Marketing Hearings 1974.

United States Tariff Commission, 1937. United States-Philippine Trade, Report No. 118, Second Series, U.S. Government Printing office 
Number

Author

2444

Tadashi Yamada

Tetsuji Yamada and

Frank Chaloupka

2445 Peter Schmidt and

Ann Dryden Witte

2446 Robert J. Shiller

2447 Carol L. Osler

2448 David E. Bloom and Richard $B$. Freeman

2449 Charles Engel and Kenneth Kletzer

2450 Danny Quah

2451 Shlomo Yitzhaki and Joel slemrod

2452 Randi Boorstein and Robert C. Feenstra

2453 Robert C. Feenstra

2454 Robert J. Gordon

2455 Jeffrey Sachs and Harry Huizinga

2456 Robert C. Harris Julian Franks and

2457 Manuel Trajtenberg

2458 Dagobert L. Brito Jonathan H. Hamilton Steven M. Slutsky and Joseph E. Stiglitz
Title

Date

Nutrition and Infant Health in Japan

$11 / 87$

Predicting Criminal Recidivism Using

$11 / 87$

"Split Population" Survival Time Models

Investor Behavior in the October 1987

Stock Market Crash: Survey Evidence

$11 / 87$

Factor Prices and Welfare Under Integrated 11/87 Capital Markets

Economic Development and the Timing and

$11 / 87$

Components of Population Growth

Trade Policy Under Endogenous Credibility

$11 / 37$

What Do We Learn From Unit Roots in

$12 / 87$

Macroeconomic Time Series?

Welfare Dominance: An Application to

$12 / 87$

Commodity Taxation

Quality Upgrading and its Welfare Cost

in U.S. Steel Imports, 1969-74

$12 / 87$

Symmetric Pass-Through of Tariffs and

Exchange Rates Under Imperfect Competition:

An Empirical Test

Wage Gaps vs. Output Gaps: Is There a Common Story for All of Europe?

$12 / 87$

U.S. Commercial Banks and the Developing

$12 / 87$ Country Debt Crisis

Means of Payment in Takeovers: Results

$12 / 87$ for the U.K and U.S.

Patents, Citations and Innovations:

$12 / 87$

Tracing the Links

Information and Multi-Period Optimal

$12 / 87$

Income Taxation with Government Commitment

Trigger Strategies and Price Dynamics in 